\title{
Evidence of oxygenic phototrophy in ancient phosphatic stromatolites from the Paleoproterozoic Vindhyan and Aravalli Supergroups, India
}

\author{
T. Sallstedt ${ }^{1,2}$ (D) | S. Bengtson ${ }^{1,2}$ | C. Broman ${ }^{3}$ | P. M. Crill ${ }^{3}$ | D. E. Canfield ${ }^{2}$
}

${ }^{1}$ Department of Paleobiology, Swedish Museum of Natural History, Stockholm, Sweden

${ }^{2}$ Department of Biology, Nordic Center for Earth Evolution (NordCEE) and University of Southern Denmark, Odense, Denmark

${ }^{3}$ Department of Geological

Sciences, Stockholm University, Stockholm, Sweden

Correspondence

T. Sallstedt, Department of Paleobiology,

Swedish Museum of Natural History,

Stockholm, Sweden.

Email: therese.sallstedt@nrm.se

Funding information

Danmarks Grundforskningsfond, Grant/Award Number: DNRF53; Vetenskapsrådet, Grant/ Award Number: 2010-3929 and 2013-4290

\begin{abstract}
Fossil microbiotas are rare in the early rock record, limiting the type of ecological information extractable from ancient microbialites. In the absence of body fossils, emphasis may instead be given to microbially derived features, such as microbialite growth patterns, microbial mat morphologies, and the presence of fossilized gas bubbles in lithified mats. The metabolic affinity of micro-organisms associated with phosphatization may reveal important clues to the nature and accretion of apatite-rich microbialites. Stromatolites from the $1.6 \mathrm{Ga}$ Chitrakoot Formation (Semri Group, Vindhyan Supergroup) in central India contain abundant fossilized bubbles interspersed within fine-grained in situ-precipitated apatite mats with average $\delta^{13} \mathrm{C}_{\text {org }}$ indicative of carbon fixation by the Calvin cycle. In addition, the mats hold a synsedimentary fossil biota characteristic of cyanobacterial and rhodophyte morphotypes. Phosphatic oncoid cone-like stromatolites from the Paleoproterozoic Aravalli Supergroup (Jhamarkotra Formation) comprise abundant mineralized bubbles enmeshed within tufted filamentous mat fabrics. Construction of these tufts is considered to be the result of filamentous bacteria gliding within microbial mats, and as fossilized bubbles within pristine mat laminae can be used as a proxy for oxygenic phototrophy, this provides a strong indication for cyanobacterial activity in the Aravalli mounds. We suggest that the activity of oxygenic phototrophs may have been significant for the formation of apatite in both Vindhyan and Aravalli stromatolites, mainly by concentrating phosphate and creating steep diurnal redox gradients within mat pore spaces, promoting apatite precipitation. The presence in the Indian stromatolites of alternating apatite-carbonate lamina may result from local variations in $\mathrm{pH}$ and oxygen levels caused by photosynthesis-respiration in the mats. Altogether, this study presents new insights into the ecology of ancient phosphatic stromatolites and warrants further exploration into the role of oxygenproducing biotas in the formation of Paleoproterozoic shallow-basin phosphorites.

KEYWORDS

cyanobacteria, gas bubbles, microbial mats, phosphatization, phosphorites
\end{abstract}

\section{1 | INTRODUCTION}

The Proterozoic Eon was a time of major transitions on Earth. In addition to the pervasive oxygenation of atmosphere and ocean that begun the so-called great oxygenation event (GOE) at $2.4 \mathrm{Ga}$ (Canfield \& Teske, 1996; Holland, 2002, 2006; Lyons, Reinhard, \& Planavsky, 2014), vast continental shelf basins developed worldwide in the Paleoproterozoic Era as a consequence of crustal growth (Fedonkin, 2003). These newly 
developed shallow-marine niches provided the perfect backdrop for abundant growth of primary producing biomass (Fedonkin, 2003; Papineau, 2010; Papineau et al., 2009). As the most illustrious pioneers in the oxygen-manufacturing business, ancestral cyanobacteria were the only organisms with the capacity to produce free oxygen on the scale needed to set off the initial oxygenation of atmosphere and oceans (Papineau, 2010). They have a deep evolutionary history (Schirrmeister, Antonelli, \& Bagheri, 2011; Schopf, Kudryavtsev, \& Sergeev, 2010), reflected in the fossil record mainly through their involvement, active (see e.g., Arp, Reimer, \& Reitner, 2001; Merz, 1992) or as mere substrates (Jones, Renaut, \& Konhauser, 2005; Konhauser, Phoenix, Botrell, Asams, $\&$ Head, 2001), in microbialite accretion (Burne \& Moore, 1987).

Laminated microbialites, stromatolites, are formed through complex interplay between micro-organisms and the environment (Burne \& Moore, 1987; Dupraz, Fowler, Tobias, \& Visscher, 2013; Dupraz \& Visscher, 2005; Dupraz, Visscher, Baumgartner, \& Reid, 2004; Grotzinger \& Knoll, 1999; Reid et al., 2000; Stal, 2000). Abundant types of microbial metabolisms together influence the geochemistry of microbial mats (Baumgartner et al., 2009) and lead to the formation of biological fabrics, which may be preserved in the fossil record as indicators of past microbial responses to changes in light, chemical, or sedimentary regimes (Allwood, Walter, Burch, \& Kamber, 2007; Allwood, Walter, Kamber, Marshall, \& Burch, 2006; Grotzinger \& Knoll, 1999; Sumner, 1997; Walter, 1972). As the main builders of stromatolites (Grotzinger \& Knoll, 1999; Stal, 2000), microbes, in particular cyanobacteria, influence stromatolite lamination on a micro-level and also exert considerable control on the macro-scale morphology of accreting stromatolites (Dupraz \& Visscher, 2005; Grotzinger \& Knoll, 1999; Reid et al., 2000; Riding, 2000). The issue of biogenicity sometimes challenges the interpretation of ancient microbialite-like structures, but still, a most conspicuous task lies in deciphering what the preserved morphological features reveal about the paleoecology of a microbial system (e.g., Shepard \& Sumner, 2010; Sumner, 1997). At best, the synsedimentary preservation of bona fide fossils provides an important clue, but in most cases other features must be relied upon to understand the environmental and metabolic forces at play within a sedimentary microbial system (Allwood et al., 2006, 2007; Grotzinger \& Knoll, 1999). The aim of this study was to investigate the paleoecology of microbial mats from the Paleoproterozoic Chitrakoot Formation of the Vindhyan Supergroup and the Jhamarkotra Formation of the Aravalli Supergroup (Figure 1), representing some of the oldest examples of massive phosphogenesis on Earth. More specifically, we mean to evaluate the morphological biosignatures and types of metabolism that were likely associated with the accretion of apatite-rich stromatolites at these locations.

A most fundamental textural component of ancient microbialites is micro- to mesoscale laminations, which, depending on continuity, thickness, and inclination, result in a variety of stromatolite shapes and forms, many of which have been thought unique to the Precambrian Earth (e.g., Batchelor, Burne, Henry, \& Jackson, 2004; Walter, 1972). Numerous filamentous microbes are able to glide up and down rapidly within microbial mats as a response to external (light irradiation, sedimentation) or internal (distribution of dissolved inorganic carbon, DIC, and other chemical species) stimuli associated with the mat (Alexandre, Greer-Phillips, \& Zhulin, 2004; Fenchel \& Kuhl, 2000; Garcia-Pitchel,
Mechling, \& Castenholz, 1994; Hoiczyk, 2000). This phenomenon leads to the formation of specific textural components in ancient mats, many of which are distinctly biological. Examples of this are the formation and preservation in the rock record of reticulated fabrics or tufted microbial mats (Shepard \& Sumner, 2010; Sumner, 1997; Walter, Bauld, \& Brock, 1976). Opinions differ as to what information can be obtained from these kinds of microbial fabrics; Walter et al. (1976) argued that tufted microbial mats, a result of the initial random gliding of filamentous cyanobacteria, also reflect the organisms' responses to incoming light and thus can be used as a proxy for cyanobacterial phototaxis in the fossil record. This opinion was recently challenged by Shepard and Sumner (2010) who, during laboratory experiments with motile cyanobacterial Pseudanabaena strains, showed that while cyanobacterial communities indeed form tufted mats, pillars, and reticulate structures, the morphological expressions of these fabrics are the results of undirected, nonphototactic, gliding and as such do not attest to the phototrophy of a mat system. On the other hand, the formation of tufts and reticulated mats, while not solid evidence of phototrophy in the rock record, does reflect the presence of motile, filamentous communities and as such provides evidence for biogenicity (Sumner, 1997).

Perhaps a more convincing structural proxy of photoautotrophic metabolism is the preservation of oxygen bubbles produced by cyanobacteria in zones of active photosynthesis, sometimes later preserved as spherical or nearly spherical porosities within laminated microbialites (e.g., Bosak, Liang, Sim, \& Petroff, 2009; Bosak et al., 2010; Guido \& Campbell, 2014; Mata et al., 2012). These structures can be seen forming in active microbial mats and precipitates from hydrothermal pools and other modern settings where microbial mats abound (e.g., Arp, Hofman, \& Reitner, 1998; Bosak et al., 2009, 2010; Guido \& Campbell, 2014; Jones et al., 2005; Love, Simmons, Parker, Wharton, \& Seaburg, 1983). Primary porosity in the form of metabolically produced oxygen bubbles has also been reported from several fossil microbialites, most notably from conical stromatolites similar to the Precambrian form Conophyton (Bosak et al., 2009, 2010) but also from oncoid-like microbialites constructed by oxygenic phototrophs (Wilmeth et al., 2015).

While siliceous and carbonate microbialites are rather evenly dispersed in the rock record (Grotzinger \& Knoll, 1999), the distribution of phosphatic stromatolites is somewhat more lopsided (Papineau, 2010), with major deposition episodes at the beginning and end of the Proterozoic Eon (Papineau, 2010; Papineau et al., 2009). Tubular fabrics resembling filamentous mineralized sheaths can be important constituents of the overall fabric in phosphorites (Alvaro \& Clausen, 2010; Krajewski, 2011) suggesting that filamentous micro-organisms play an important role in the accumulation of phosphate (Sergeev, Gerasimenko, \& Zavarzin, 2002). However, the metabolic affiliation of these apatite-encrusted fabrics is uncertain.

Our study emphasizes the importance of oxygenic photosynthesizing micro-organisms and their extracellular polymeric substances (EPS) in the concentration of phosphate and subsequent accretion of Paleoproterozoic phosphatic stromatolites from India. This phenomenon was primarily manifested by the preservation of tufted microbial mats and mineralized bubble-like structures within fine-grained apatite laminae in both columnar and oncoid cone-shaped stromatolites from 
the Vindhyan and Aravalli Supergroups. The presence in Vindhyan stromatolites of complex algae of probable rhodophyte affinity (Bengtson, Sallstedt, Belivanova, \& Whitehouse, 2017) further supports the idea of lavish blooms of phosphate-concentrating phototrophic biotas inhabiting shallow niches in the Vindhyan marine realm.

\section{2 | MATERIALS AND METHODS}

\section{1 | The Vindhyan Supergroup}

The Vindhyan Supergroup (Figure 1) in central India represents one of many intracontinental basins that developed worldwide in the Proterozoic Eon (Chakraborty, 2006). Sediment was deposited within basins in shallow epeiric seas, a type of setting that became widespread after 2.5 Ga (Chakraborty, 2006; Harries, 2009; Mata et al., 2012). The Vindhyan Supergroup is composed of slightly deformed, but on the whole unmetamorphosed, sedimentary siliciclastic rocks, shale, and limestone of presumed marine origin (Bose, Sarkar, Chakrabarty, \& Banerjee, 2001). It is traditionally divided into the Lower and Upper Vindhyan sequences and exhibits a total thickness of approximately 4,500 m (Bose et al., 2001). Vindhyan exposures are divided into three major sectors: The Son Valley, Bundelkhand, and Rajasthan sectors, each separated by unconformities (Chakraborty, 2006). The Son Valley sector has an ENE-WSW strike and is approximately $3000 \mathrm{~m}$ thick (Chakraborty, 2006). The Tirohan Dolomite of the Lower Vindhyan Chitrakoot Formation has a $\mathrm{Pb}-\mathrm{Pb}$ isochron age of approximately $1.6 \mathrm{Ga}$ (Bengtson, Belivanova, Rasmussen, \& Whitehouse, 2009), a date that is supported by other geochronological work in the region (reviewed by Bengtson et al., 2017).

A total of 15 samples of phosphatic-dolomitic stromatolites were collected in 2006 and 2011 from the Tirohan Dolomite in the Jankikund section $\left(\mathrm{N} 25^{\circ} 09^{\prime} \mathrm{E} 080^{\circ} 52^{\prime}\right)$ along the Paisuni riverbank in Chitrakoot. The town of Chitrakoot is located on the border between the Satna district of Madhya Pradesh and the Banda district of Uttar Pradesh in central India (Figure 1, right star). The approximately 100-m-thick Tirohan Dolomite unit (Joshi, Azmi, \& Srivastava, 2006) is unconformably overlain by the Upper Vindhyan siliciclastic Kaimur Formation. The Tirohan unit contains dolomitic-phosphatic stromatolites, unbranched, and columnar in shape, around $10 \mathrm{~cm}$ in diameter, with the phosphate mainly present in the form of intercolumnar clasts, rims or internal laminae. Smaller, cm-sized, phosphatic stromatolites are also present. The intercolumnar clasts were interpreted by Bengtson et al. (2009) as ripped-off microbial mat chips, redeposited in the matrix between columns. Laminated phosphate that surrounds many dolomite columns represents phosphatized microbial mats.

\section{2 | The Aravalli Supergroup}

The Paleoproterozoic Aravalli Supergroup (Figure 1) is well exposed close to the city of Udaipur in Rajasthan, northwest India. The rocks have been subjected to a low-grade metamorphism, in the range of lower greenschist (Chauhan, 1979), and consist of sedimentary rocks unconformably overlying an Archaean basement of gneiss known as the Banded Gneiss Complex, BGC (Roy \& Paliwal, 1981). The Supergroup is divided into the Lower, Middle, and Upper Aravalli sequences. The stromatolite phosphate-bearing Jhamarkotra formation is approximately $35 \mathrm{~m}$ thick (Papineau, 2010). The Lower Aravalli constitutes a marine transgressional sequence and was deposited in an active rift basin (e.g., Roy \& Paliwal, 1981). Phosphatic rocks of the Aravalli constitute an economically important source of phosphate, and they are quarried in one of the world's largest open-pit phosphate mines, the Jhamarkotra phosphate mine. The age of the Lower Aravalli has traditionally been reported as early Paleoproterozoic with $\mathrm{Pb}-\mathrm{Pb}$ isochrone ages around 2-2.5 Ga (Chauhan, 1979; Papineau, 2010; Schleicher, Todt, Viladkar, \& Schmidt, 1997). However, geochronological and stratigraphic dating in a recent study by McKenzie et al. (2013) suggests a later deposition of the Aravalli Jhamarkotra formation around $1.7 \mathrm{Ga}$, closer to that of the Lower Vindhyan phosphorites, stressing the importance of further geochronological investigation into this region (e.g., McKenzie et al., 2013; Melezhik, Purohit, \& Papineau, 2014). A total of 18 samples were sampled along a transect from the Jhamarkotra mine in January 2011. These were mainly phosphatic stromatolites in carbonate matrix.

\subsection{Acid maceration}

A 10\% acetic acid solution was used according to the standard protocol for carbonate dissolution (e.g., Jeppsson, Fredholm, \& Mattiasson, 1985) in order to free phosphatic microbial fossils from the surrounding carbonate matrix. After maceration of phosphatic stromatolites in buffered acetic acid-filled trays, the remaining phosphatic debris was separated into four size fractions (>1 mm; $1-0.25 \mathrm{~mm}$; $0.25-$ $0.063 \mathrm{~mm}$, and $<0.063 \mathrm{~mm}$ ), washed in tap water, and dried overnight at $60^{\circ} \mathrm{C}$. A Nikon SMZ-1000 Stereomicroscope was used to handpick fossils primarily from the 1 - to $0.25-\mathrm{mm}$ fraction for further microscopic analysis.

\subsection{Stable isotope spectroscopy}

A Thermo Delta $\vee$ Advantage mass spectrometer was used to measure the isotopic composition of organic carbon $\left(\delta^{13} C_{\text {org }} \%\right.$ V-PDB) and total nitrogen $\left(\delta^{13} \mathrm{~N}_{\text {air }} \%\right.$ ) on decarbonated sediment samples containing phosphatic stromatolites from the Vindhyan Supergroup, Jankikund. Samples consisted of previously untreated slabs of rock containing bubble-like spherical objects interspersed within phosphatic microbial mats. The results were calibrated against the Protein (Casein) Standard OAS (IVA 33802155, Batch No 114859), and the precision was evaluated via High Organic Sediment Standard OAS Certificate 114522 (IVA33802151, Batch no: BN114522). Based on replicate analyses of the standards, we report the isotopic carbon composition relative to the Vienna PeeDee Belemnite (V-PDB) within an error of $0.16 \%$. The isotopic composition of total nitrogen relative to air is reported within an error of $0.21 \%$, based on replicate analyses of the standards. 


\section{5 | Raman spectroscopy}

Phosphatic thin sections and hand specimens from the Vindhyan Supergroup were analyzed using a confocal laser Raman spectrometer (Horiba instrument LabRAM HR 800), equipped with a multichannel Peltier-cooled $\left(-70^{\circ} \mathrm{C}\right) 1024 \times 256$ pixel CCD (charge-coupled device) array detector. A 514-nm excitation Argon laser (Melles Griot 543) with a rather low laser power of $1 \mathrm{~mW}$ at the sample surface was used to avoid heat-induced damage of the specimens, and all spectra on carbonaceous matter were recorded subsurface below the enclosing transparent phase to avoid any effects that may have been produced during sample preparation. The laser beam was focused through a $100 \times$ objective to obtain a spot size with a diameter of about $1 \mu \mathrm{m}$ using an Olympus BX41 microscope, and the $800 \mathrm{~mm}$ focal length spectrograph of the LabRAM HR gives a spectral resolution of about 0.4 per $\mathrm{cm} /$ pixel. Acquisitions were collected using a grating of 1800 lines $/ \mathrm{mm}$ and a slit of $300 \mu \mathrm{m}$. Repeated use of a silicon wafer calibration standard with a characteristic Raman line at 520.7 per $\mathrm{cm}$ was used to control the accuracy of the spectral features. Each spectrum was acquired for $5 \times 10 \mathrm{~s}$ in multiwindow mode over a range of 100-4,000 per $\mathrm{cm}$. The instrument was controlled, and Raman data were processed with the software LABSPEC version 5.78.24. All the presented spectra were baseline subtracted with polynomial fit, and the peak parameters were fitted using GaussianLorentzian functions.

\section{6 | Synchrotron X-ray Tomographic Microscopy}

Microbial fossils and fabrics, mainly recovered from acid residue, were analyzed with Synchrotron X-ray Tomographic Microscopy (SrXTM) using the TOMCAT beamline (tomographic microscopy and coherent radiology experiments) at the Swiss Light Source, Paul Scherrer Institute, Switzerland. The samples were mounted on 3-mm brass pegs and analyzed in 1501 stepwise increments over $180^{\circ}$ rotation at beam energies ranging from 19 to $30 \mathrm{keV}$. During scanning, the $20 \times$ and $10 \times$ microscope objectives were used. The resulting voxel (threedimensional pixel) size for the $20 \times$ objective was $0.37 \mu \mathrm{m}$ for specimens scanned 2012-2014 and $0.325 \mu \mathrm{m}$ for specimens scanned after February 2014. For the $10 \times$ objective, the voxel size was $0.74 \mu \mathrm{m}$ or $0.65 \mu \mathrm{m}$, respectively. During scanning, 1,501 projections were acquired equiangularly over $180^{\circ}$, online post-processed, and rearranged into flat- and darkfield-corrected sinograms. Visualization and analysis software AVIzo (FEI company, Hillsboro, US) were used for tomographic reconstructions of the resulting datasets, which consist of two-dimensional, stacked images, reconstructed using a Fourier transform method (FTM) algorithm (e.g., Marone \& Stampanoni, 2012).

\section{7 | Optical microscopy}

Samples, in the form of untreated slabs, of Jankikund and Jhamarkotra phosphatic stromatolites were cut into pieces of approximately $3.5 \times 2.5 \mathrm{~cm}$ and sent to Vancouver Petrographics, Canada, for the production of uncovered petrographic thin $(30 \mu \mathrm{m})$ and thick $(150$ and $200 \mu \mathrm{m}$ ) sections. The sections were cut both vertically and horizontally through phosphatic laminated mats. They were examined using a Nikon SMZ-1000 stereomicroscope, a Leica DMLP, and an Olympus BX51 polarizing microscope equipped with an Olympus DP71 detachable camera. The software CELLSENS DIMENSION was used for imaging.

\section{8 | Environmental scanning electron microscopy (ESEM)}

Petrographic thin sections of laminated stromatolitic phosphate and phosphatic microfossils handpicked from acid residues were mounted on brass pegs or aluminum stubs and examined using a low-vacuum environmental SEM (Philips XL 30 ESEM-FEG and Quanta ESEM-FEG 650 field emission microscope) with an approximate accelerating voltage of $20 \mathrm{kV}$. Elemental analyses were performed using an Oxford EDS detector X-Max $80 \mathrm{~mm}^{2}$. The INCA suite 4.1 and AZTEC software were used for mapping and element analysis. Samples were uncoated because of the use of low vacuum.

\section{3 | RESULTS}

\subsection{Aravalli stromatolites}

The Jhamarkotra formation contains abundant stromatolites ranging from discrete columnar to branching variants together with small, steeply convex domical cone-shaped stromatolites (Figure 2a-c). Many of these morphologies have been previously described by Banerjee (1971) and Chauhan (1979). Heights of the columns range from dwarf forms of approximately $8-20 \mathrm{~mm}$ to $30 \mathrm{~cm}$. Differential weathering can be seen in some columns between susceptible carbonate and more weathering-resistant apatite (Figure 2c). Some specimens show stromatolite laminae that are nearly concentric and resemble oncoids, although no nuclei have been observed in the central part of the structures. However, the growth of the oncoidal specimens consistently develops into a directed conical type of growth, where superimposed steeply convex layers stack on top of each other (Figure 3). The stromatolites mainly consist of microcrystalline apatite and dolomite with some interstitial Si-rich phases. The phosphatic parts are primarily comprised of calcium, phosphorus, and oxygen, but carbonaceous matter is present in apatite laminae as dark inclusions, together with trace amounts of fluorine and silica (Figure S1). Previous studies of the mineralogy of the Jhamarkotra stromatolites by Papineau et al. (2016) show the primary apatite phase to be carbonate fluorapatite (francolite), consistent with the EDS data.

\subsection{1 | Microfabric characteristics of the Jhamarkotra stromatolites}

The stromatolites vary slightly with respect to form and lamina-inclination. Some examples are columnar with moderately convex domical laminae, but most specimens have steeply convex laminae that significantly 
thicken toward the middle (e.g., Figure 3b,c). Laminae either consist of irregularly sized apatite-dolomite bands, approximately 80-500 $\mu \mathrm{m}$ thick (dolomite) up to $1 \mathrm{~mm}$ thick (apatite), or they are mainly phosphatic with darker and lighter apatite bands with traces of interspersed dolomite.

The stromatolite laminae, when well preserved, show a distinct filamentous or thread-like apatitic microfabric (Figure 4a-c). The filamentous structures appear to be oriented primarily parallel to lamination (Figure $4 b, c$ ), but as column flanks are often steep, this sometimes leads to the impression of a vertical direction of the filamentous fabric. At the apical part of most of the columns, the filament-like structures morph into tufts with a clear vertical incline (Figures 3b,c, and $4 d$ ). This pattern results in considerably thickened stromatolite crests and a cone-like appearance.

\subsection{2 | Primary intralaminar porosity in Jhamarkotra stromatolites}

Fenestrae are common in the Aravalli stromatolites. In the columns with an oncoidal cone-like growth, fenestrae range in size from $200 \mu \mathrm{m}$ up to more than $1 \mathrm{~mm}$ forming irregular voids, typically in the crestal part of the structures (Figure 4e). Most abundant, however, are spheroidal to slightly irregular globules infilled with dolomite, or more seldom with a silica-rich phase or apatite (Figures $4 a-c$ and 5). Sizes vary between 50 and $500 \mu \mathrm{m}$, with a mean cross-sectional size of approximately 150-200 $\mu \mathrm{m}$. When these structures appear in stromatolites that show a well-preserved mat fabric, they are consistently interspersed in-between filamentous or thread-like fabrics that encircle them in a way similar to so-called hourglass structures described by Mata et al. (2012). These structures are interpreted as bubbles stabilized by filamentous micro-organisms (compare Figures $4 a$,b, $5 \mathrm{a}$ and $15 \mathrm{c}$,d in Mata et al., 2012 to Figure $5 \mathrm{a}-\mathrm{c}$ in this study). Knoll,
Wörndle, and Kah (2013) also reported similar structures within diagenetic chert nodules from the Upper Mesoproterozoic Angmaat Formation, Canada (compare Figure 9b,c in Knoll et al., 2013 to Figure 5 e herein). Some globular structures also appear to have been slightly compressed against each other, which resulted in small areas of foam-like fabrics (Figure 5e). A dark brown-black rim often surrounds the globules, especially where mat fabrics are less well defined (Figure 5f).

\section{2 | Vindhyan stromatolites}

Samples collected from the Lower Vindhyan Tirohan Dolomite at Jankikund consist of non-branching, columnar stromatolites, usually approximately $10 \mathrm{~cm}$ wide, with a height of $15-30 \mathrm{~cm}$ (Figure 6a). The columns are generally surrounded by a fine-grained matrix of dolomite where angular to slightly rounded microbial phosphate clasts have been redeposited (Figure 6a,b). The majority of the intercolumnar clasts are governed by the shape of their constituent microbial fabrics and appear somewhat contorted; they were thus probably not strongly lithified at breakup from the main microbial mat (Bengtson et al., 2009).

Microcrystalline dolomite constitutes a major phase of the largest stromatolites, but fossil-rich phosphate is present as laminations or as laminated rims surrounding the columns (Figure 6c,d). Smaller centimeter-sized stromatolites in the form of phosphatic columns or domes can also be found at Jankikund, and were collected for this study. Phosphate is present in the form of calcium phosphate with carbon, silica, and sometimes iron as minor constituents (see Figure S2). Stable isotope analysis of organic carbon associated with the Vindhyan microbial mats shows an average $\delta^{13} \mathrm{C}_{\text {org }}$ value of $-30.43 \%$ (std 2.69) (Table S1).

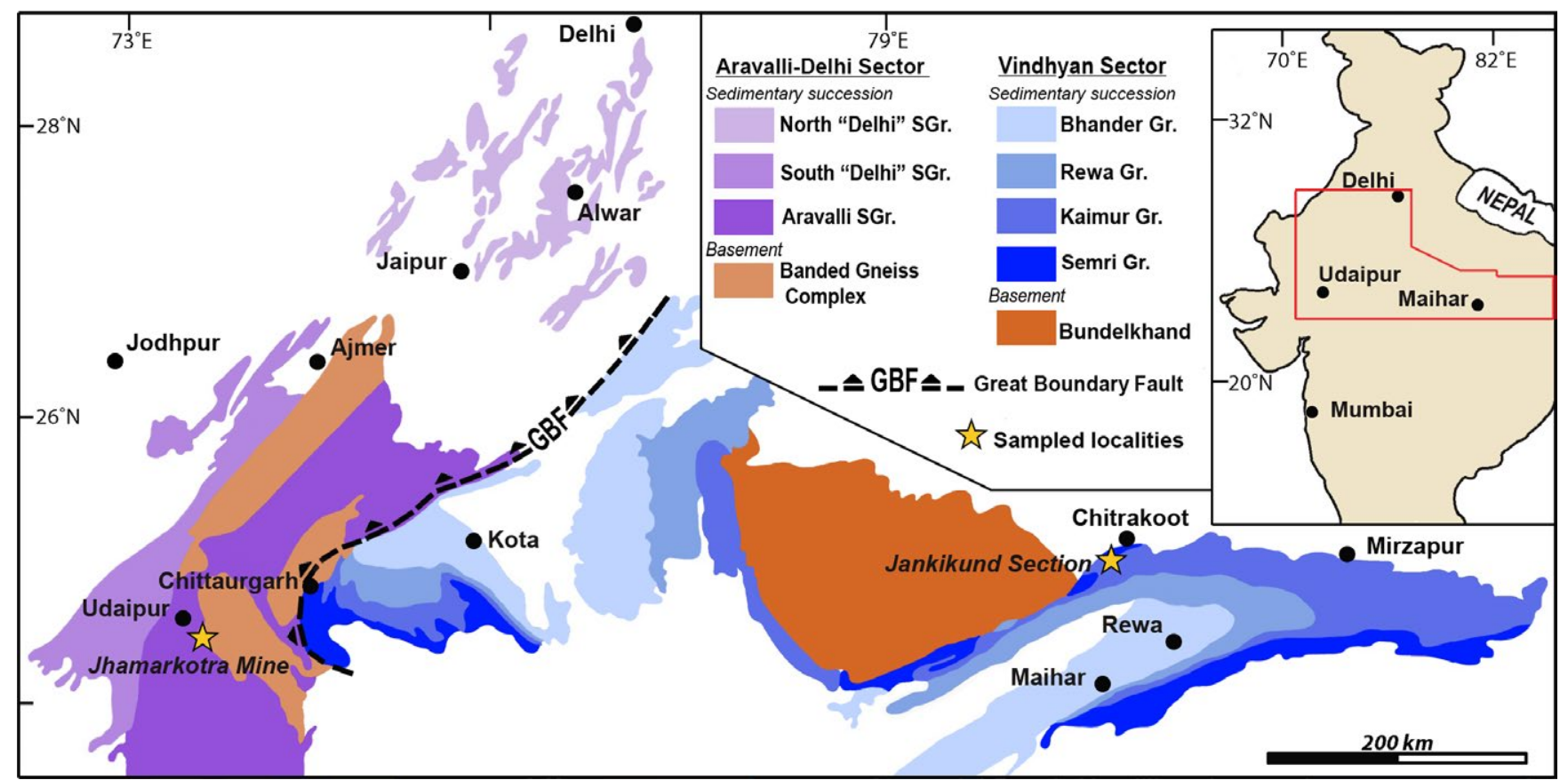

FIGURE 1 Map of central India showing the Vindhyan and the Aravalli Supergroups. After McKenzie et al. (2013) [Colour figure can be viewed at wileyonlinelibrary.com] 


\subsection{1 | Microfabric characteristics}

The Jankikund stromatolites are characterized by laminated microbial mat sequences represented by convex laminae, approximately $100-500 \mu \mathrm{m}$ thick, with a gentle upward incline. They contain alternating dark and light apatite layers (Figure 6e-g) or interbedded sequences of microcrystalline dolomite and apatite (Figure 6h). Lamination varies between fairly continuous laminae and irregular lenses or patches. While the lighter bands mainly consist of radially oriented fibrous apatite crystals forming encrusting rim, cluster, or void-filling cement (Figure 6g), Raman analysis of Jankikund mats shows that the dark apatite laminae have a considerably higher organic carbon content than the lighter bands. Raman spectroscopy confirms the organic nature of the carbon, which can be seen as characteristic $D$ and $G$ bands at 1,350 and 1,600 per $\mathrm{cm}$, respectively (Figure 7a). While carbonaceous matter is present in both light and dark apatite phases, albeit in more abundance in the darker ones, it is absent within dolomite laminae (Figure 7b), suggesting that the dolomite represents a later diagenetic phase, presumably replacing a primary calcite phase. This is also consistent with the apparent lack of fossils within dolomite parts as opposed to the apatite bands, where a fossil microbial mat biota forms the basis of laminae and functions as a framework for the Jankikund stromatolites (Figures 8 and 9). While the fossils may be present in both light and dark apatite mat layers, they are mostly confined to the dark laminae where they are abundant (Figure 6f).

\subsection{2 | Microfossils}

The Vindhyan fossil biota has been characterized by Sallstedt, Bengtson, Broman, Crill, and Canfield (2017 [submitted to Palaios]) and consists of mat-constructing filamentous and coccoidal elements as well as mat-dwelling filaments for the most part representative of other Paleo-Mesoproterozoic microbial biotas. Larger filamentous and lobate forms are interpreted as probable eukaryotic red algae (Bengtson et al., 2017). One of the most abundant types of fossil in the Jankikund assemblages is represented by large, 15-25 $\mu \mathrm{m}$ in diameter, tubular, mat-constructing filaments. These were vital in governing the shape of laminae in the Vindhyan microbial mats. The most well-preserved tubular filaments are found in phosphatic intraclasts, where they form filamentous tufts with a commonly parallel growth direction (Figure 8a,b). In situ, within the mats, the tubules are slightly less well preserved and often appear as filament or thread-like mat fabrics with a common upright to slightly inclined growth direction (Figure 8c,d). In a few samples of laminated phosphate, there are alternating erect/prostrate fabrics where the upright layers consist of tufts of tubular filaments that have been slightly melded together during recrystallization and the horizontal layers of more irregularly oriented although largely prostrate filaments (Figure 8e,f). The mat-building filaments were interpreted by Sallstedt et al. (2017 [submitted to Palaios]) to represent empty cyanobacterial sheaths similar to those of the fossil genus Siphonophycus (Schopf, 1968).

Other mat-constructing organisms in the Vindhyan stromatolites are unicellular coccoids, preserved as casts or infilled with apatite,
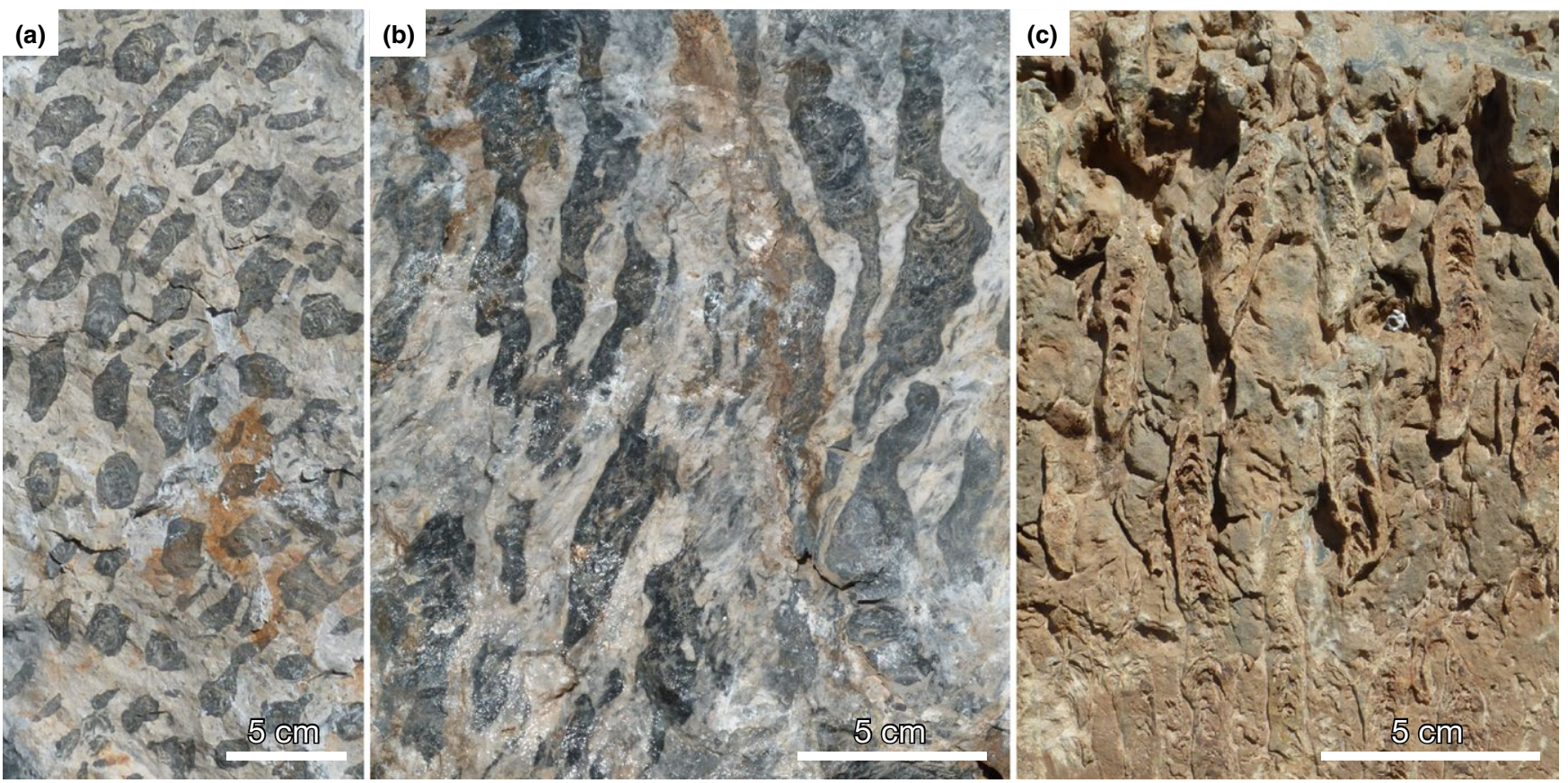

FIGURE 2 Phosphatic stromatolites from the Jhamarkotra phosphate mine, Rajasthan. (a, b) Fresh broken surfaces with mainly crosscut (a) and longitudinally cut (b) columns. (c) Differential weathering of carbonate and apatite in columns [Colour figure can be viewed at wileyonlinelibrary.com] 
varying in width between 2 and $5 \mu \mathrm{m}$ (Figure 9a,b). These organisms form slightly wavy laminae comprised of thousands of specimens and are one of the most abundant types of fossils within the mats. Matdwelling elements are mainly represented by lightly curved or coiled 6- to $10-\mu \mathrm{m}$-wide filaments occurring as single specimens or in smaller groups within dark apatite laminae (Figures $6 f$ and 9c). They are either preserved as molds in apatite or fully or partly infilled by apatite and vary from dark brown-orange to black when seen in transmitted light. Often a faded rim of encrusting apatite surrounds the filaments (Figure 9c, arrows).
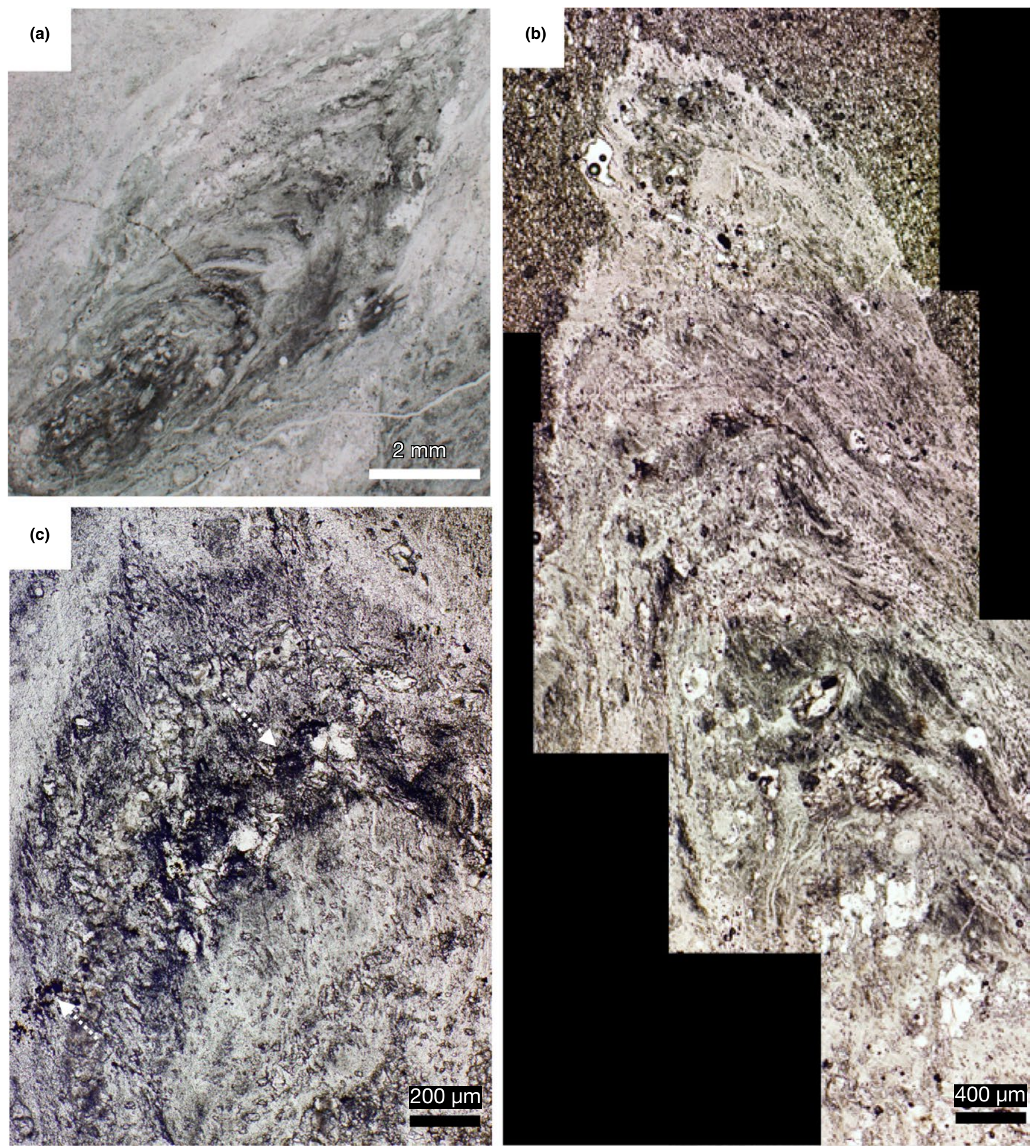

FIG URE 3 Oncoidal conical stromatolites from Jhamarkotra. (a) Globular objects within black apatite laminae. (b) Convex conical laminae; arrows point to dark kerogenous matter. (c) Convex conical laminae that thicken toward the middle [Colour figure can be viewed at wileyonlinelibrary.com] 
Macroscopic thalli found in situ within phosphatic mats in the Jankikund stromatolites show a remarkable cellular organization and have been described in detail as probable red algae by Bengtson et al. (2017). They have even cell walls and display characters suggestive of a thalloid morphotype (Figure 9d,e). This includes a pseudoparenchymatous organization of cells leading to outward splaying "cellfountain" structures (Figure 9e) similar to those of phosphatized algal thalli described by Zhang, Yin, Xiao, and Knoll (1998), among others,

from the Ediacaran phosphatic Doushantuo Formation, China.

\subsection{3 | Primary intralaminar porosity}

The stromatolitic apatite laminae are characterized by abundant globular objects of different sizes (Figures 6e, h, 8d, and 10). These objects can be (a)

(a)

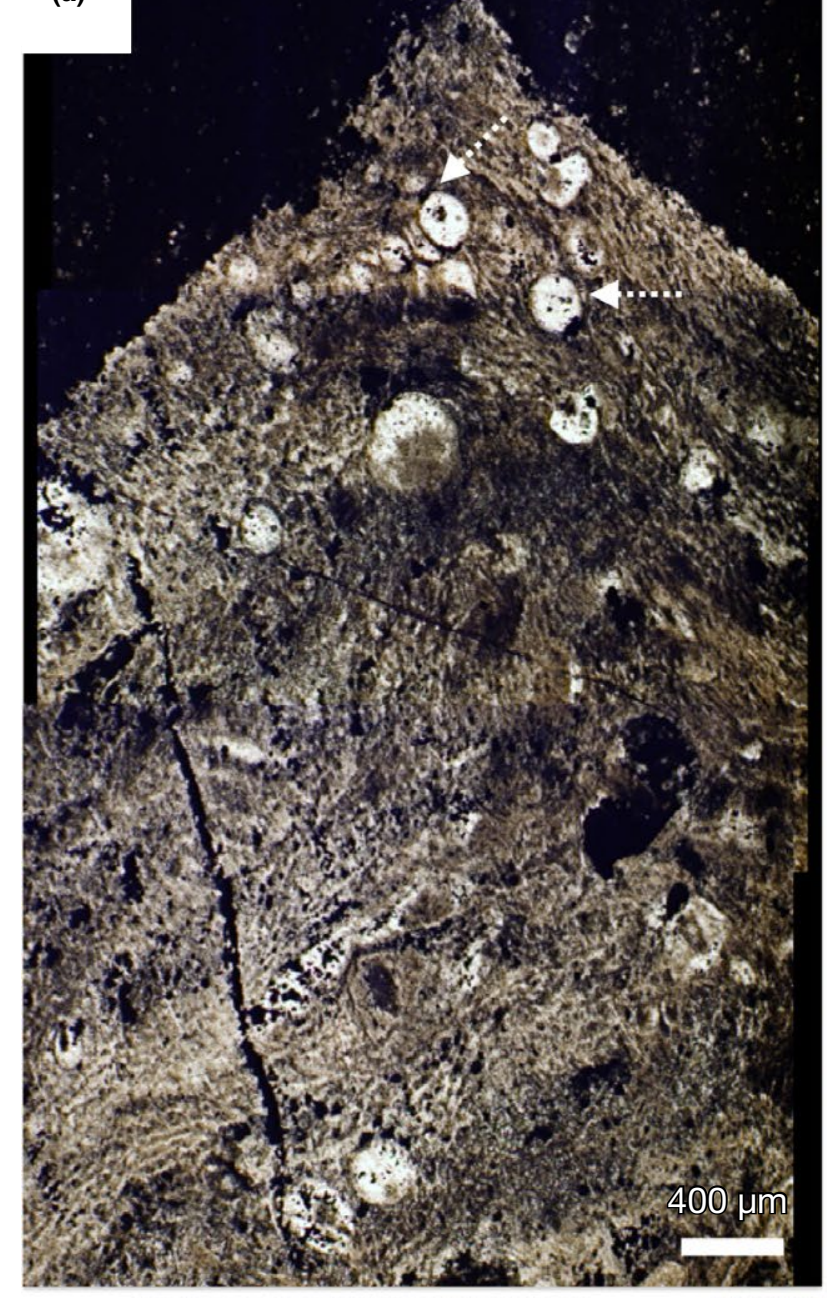

(c)

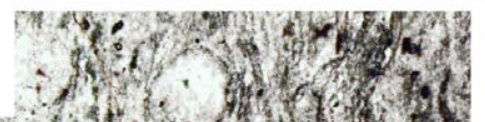

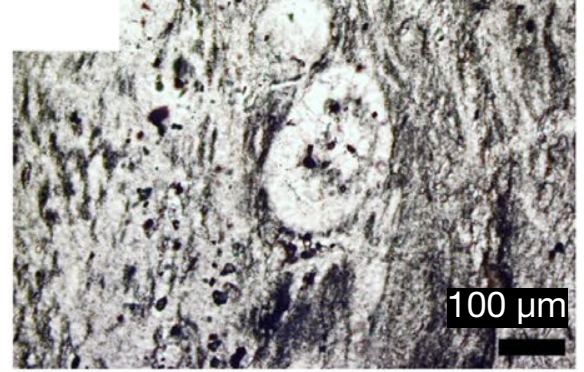

(d)

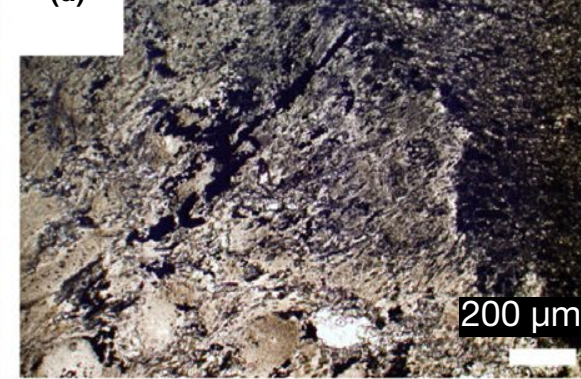

(b)
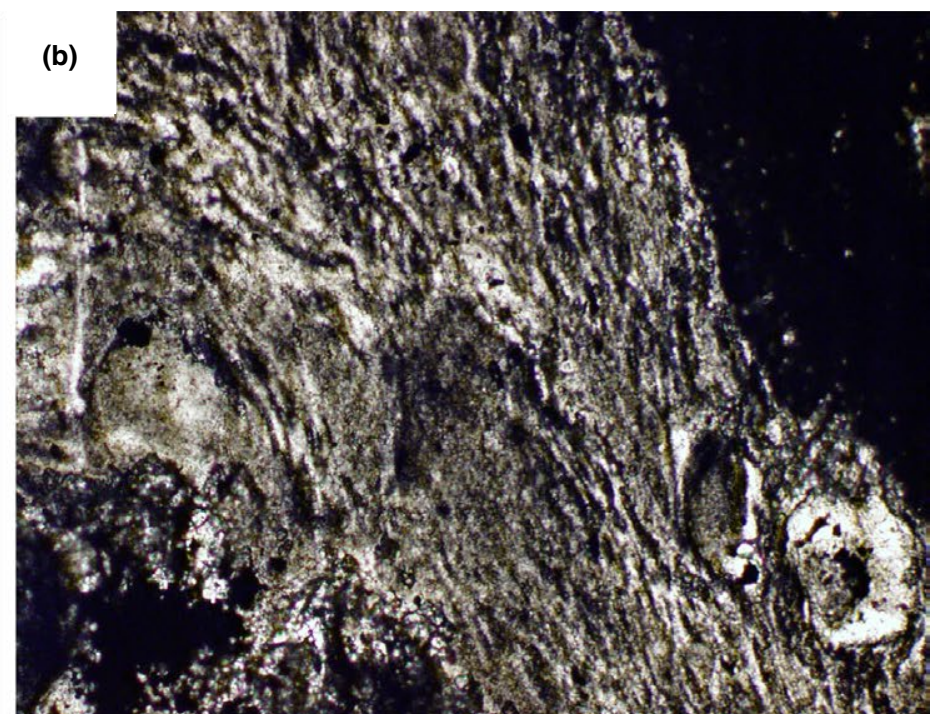
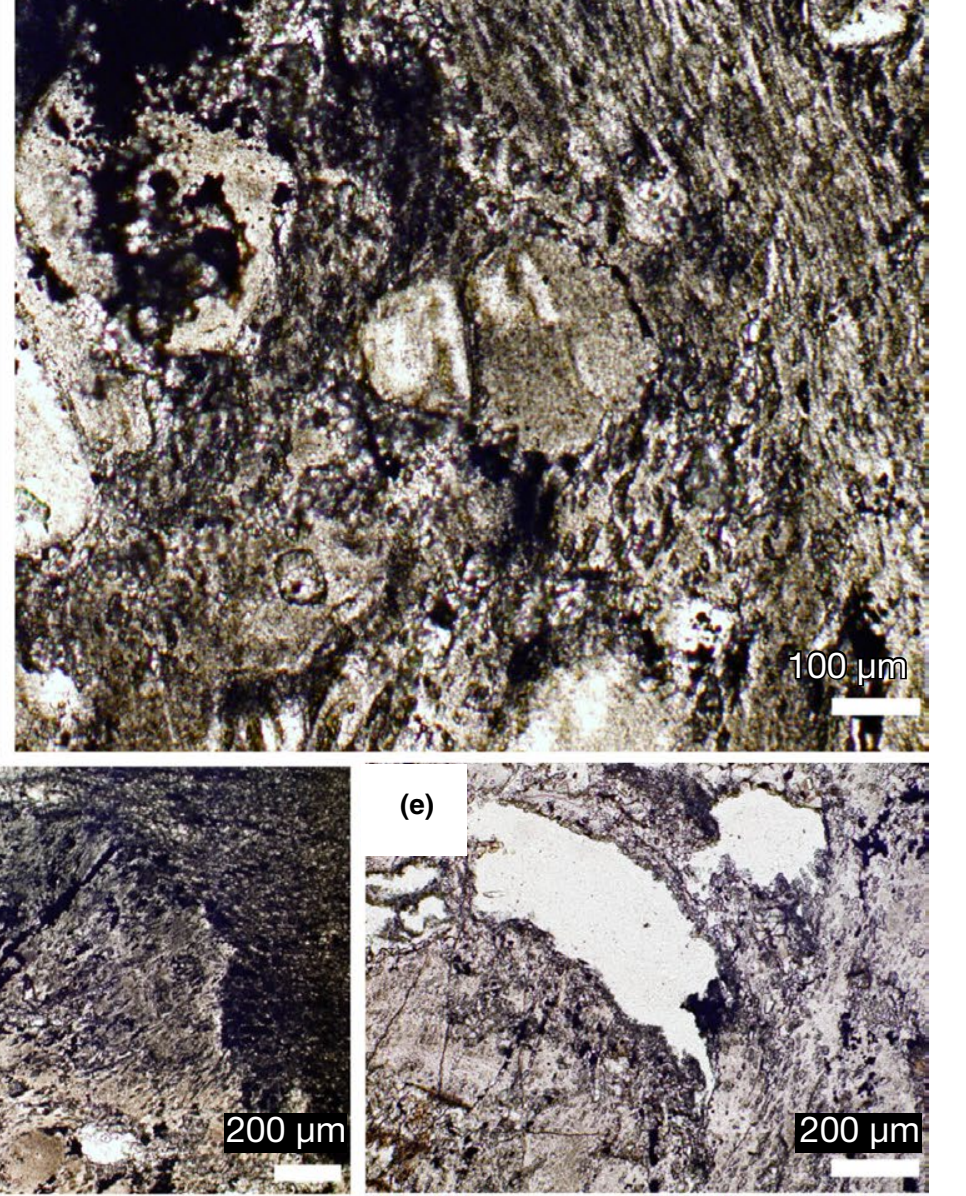

FIGURE 4 Stromatolite filamentous fabrics from Jhamarkotra. (a) Globular objects interspersed within the fabric. (b) Close-up of filamentous fabric from same specimen as (a), with filamentous structures oriented parallel to the steeply inclined laminae. (c) Filamentous fabrics surrounding globular objects (d) Tuft-like stromatolite apex. (e) Fenestrae in crestal area [Colour figure can be viewed at wileyonlinelibrary.com] 
found in tightly compressed groups, resembling a somewhat distorted foamy fabric (Figure 10a) or in groups that have mostly retained their individual spheroidal morphologies (Figure 10b-f). The globules can be empty, partly infilled with apatite, or infilled with secondary dolomite. They are concentrated in the dark biofilm bands (e.g., Figure 10f,g), and the size of the globules ranges from approximately $50 \mu \mathrm{m}$ to approximately $1 \mathrm{~mm}$. The outer surface is usually smooth, but some specimens have a thin encrusting granular layer (Figure 10c). This layer does not penetrate into the contact zone between adjacent globules (Figure 10d), indicating that it formed from the outside during diagenesis. Void-filling apatite often forms a 5- to 30- $\mu$ m-thick rim over the internal wall of the globules (Figure 10g-i). The remaining interior of the globules is either empty or filled with secondary calcite or dolomite, occasionally with irregular material (Figure 10i). The apatite matrix surrounding the globules is often smooth, but sometimes filament or thread-like fabrics enclose the globules (Figures 8d and 10c) in a way resembling the Aravalli globules (e.g., Figures $4 a-c$ and 5). Tufted filamentous fabrics in the Vindhyan mats were sometimes found in association with larger irregular fenestrae infilled with diagenetic dolomite (Figure 11a-c).

\section{4 | DISCUSSION}

\subsection{Activity of motile filamentous micro-organisms in the Vindhyan and Aravalli stromatolites}

Recent dating of the Lower Aravalli Jhamarkotra Formation suggests that the Aravalli phosphorites are likely closer in age to the $1.6 \mathrm{Ga}$ phosphatic Vindhyan stromatolites than previously recognized (see discussions in McKenzie et al., 2013, 2014; Melezhik et al., 2014; Papineau et al., 2016). This new age was based on a large population
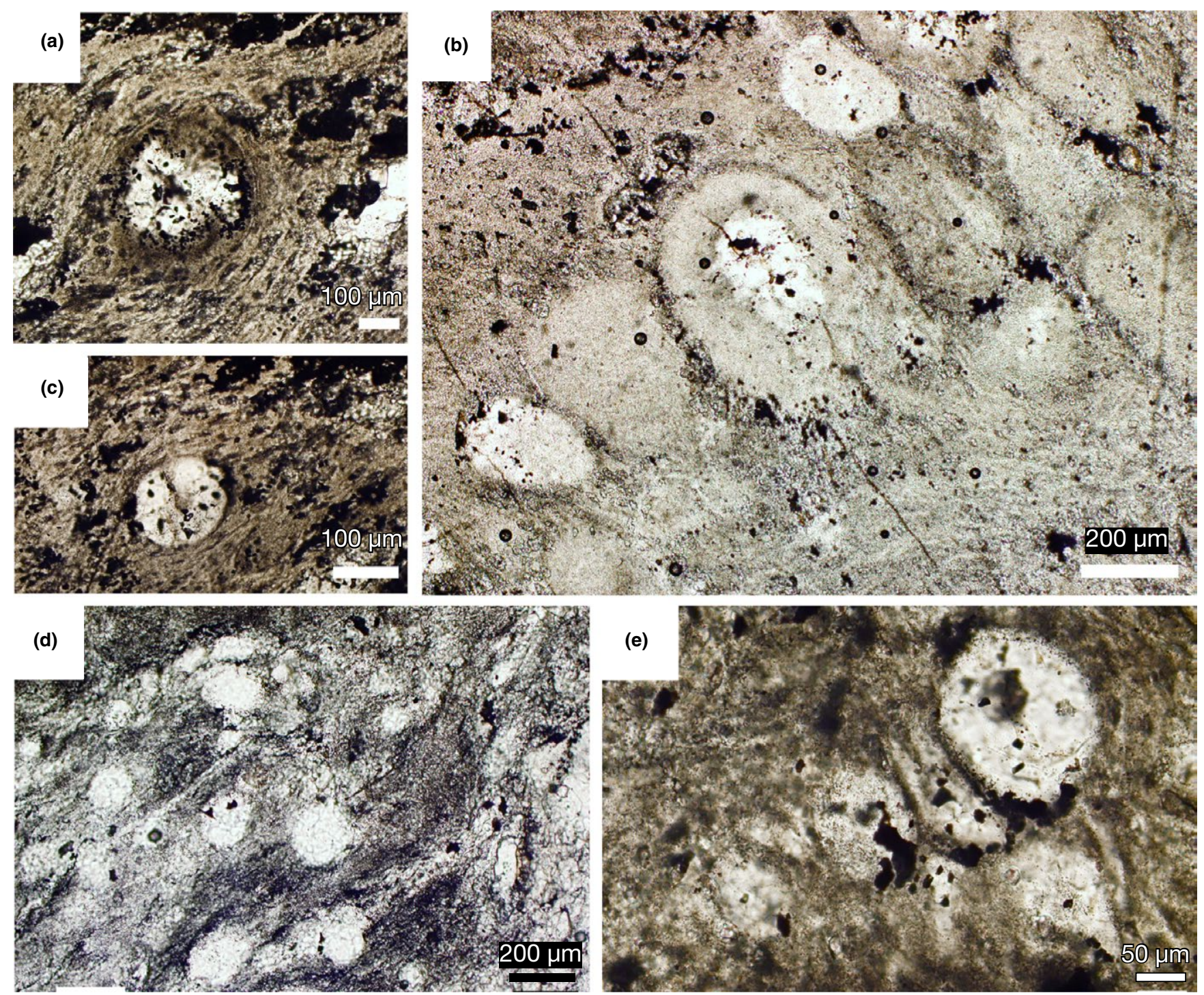

FIGURE 5 Globular objects in Jhamarkotra phosphatic stromatolites. (a) Detail showing spherical globule enmeshed in a filamentous fabric. (b) Assemblage of globules with dark lining in degraded filamentous fabric. (c) Spherical globule enmeshed in a filamentous fabric (d) Abundant globular objects of varying size. (e) Slightly compressed "foamy" globules enmeshed within a filamentous fabric [Colour figure can be viewed at wileyonlinelibrary.com] 

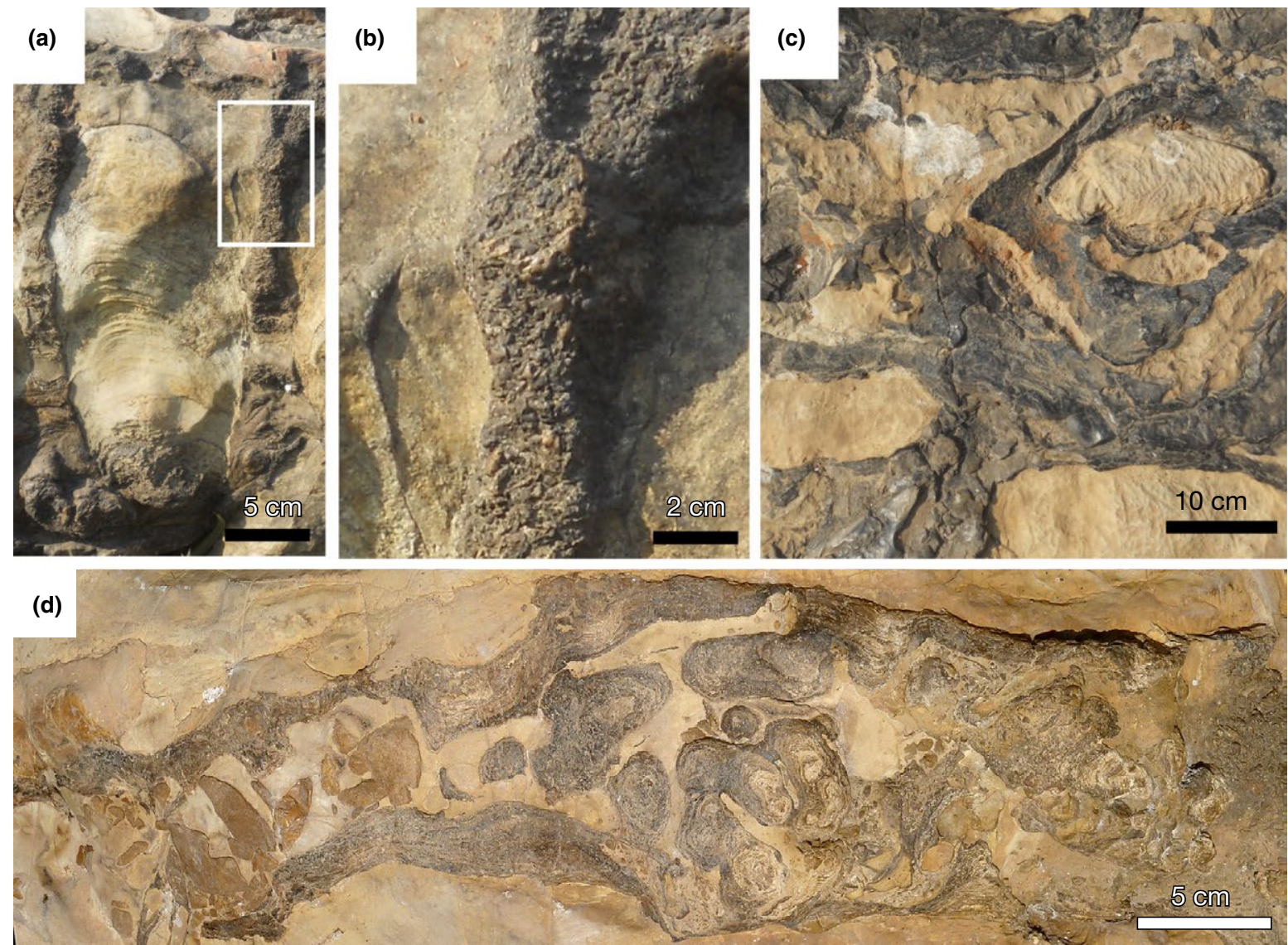

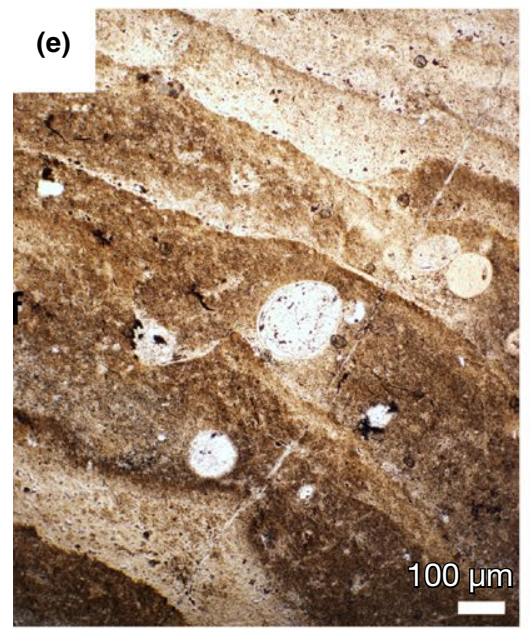

(g)

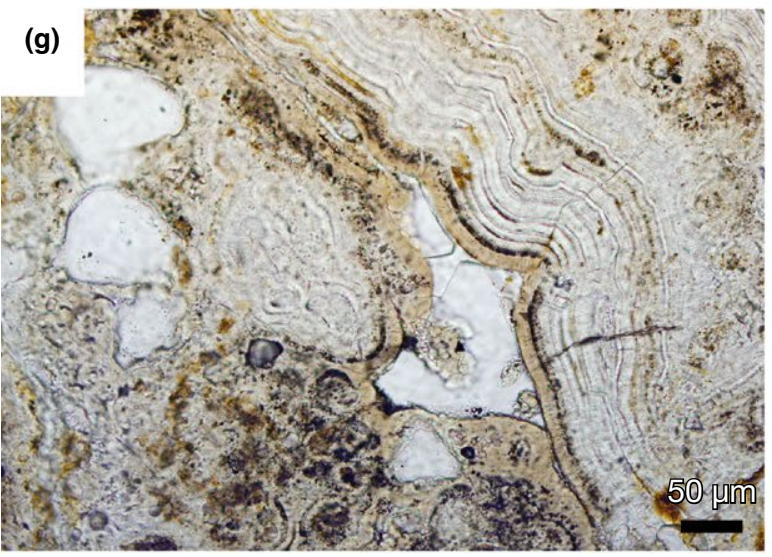

(f) 2.

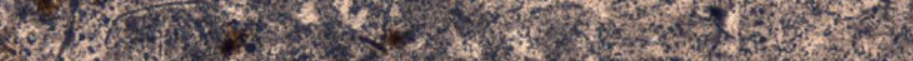

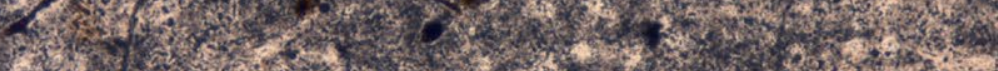

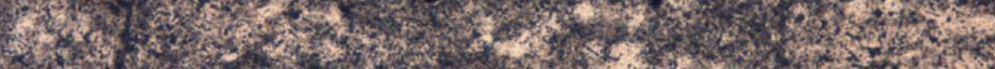

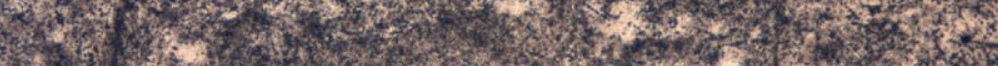

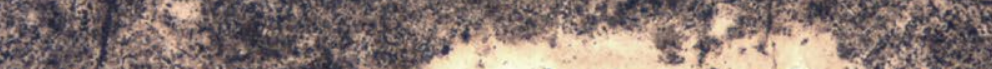
7.

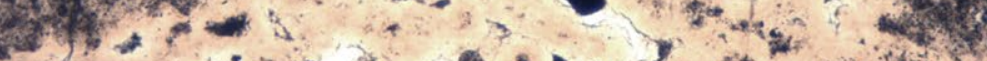

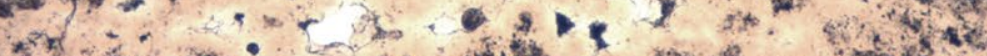

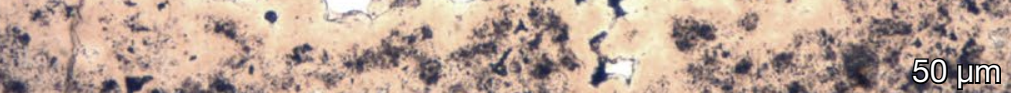

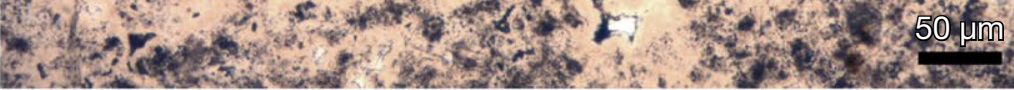

(h)

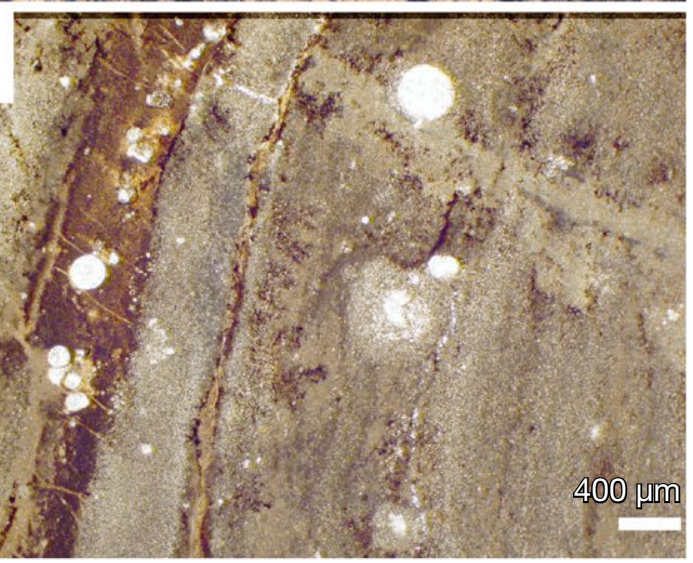


FIGURE 6 Phosphatic/dolomitic stromatolites from Jankikund, Chitrakoot. Field photographs (a-d) and thin section (e-h). (a) Columnar stromatolite with a thick rim of phosphatic intercolumnar material deposited around the columns. Frame shows position of (b). (b) Close-up of intercolumnar material from (a). (c) Thick-laminated phosphate (black) around stromatolites (d) Outcrop showing cross-sectional view of crevice lined with phosphatic stromatolites (black). (e) Light and dark apatite laminae with abundant globular structures, preferentially in the dark apatite. (f) Light and dark apatite laminae showing filamentous fossils (dark) and void-filling/cluster apatite (light). (g) Several generations of fibrous rim and void-filling apatite creates laminated diagenetic crusts in Jankikund stromatolite. (h) Alternating dark apatite and light gray microcrystalline dolomite laminae. Note globular objects infilled with dolomite in the apatite layers [Colour figure can be viewed at wileyonlinelibrary.com]

of detrital zircon grains giving $\mathrm{U}-\mathrm{Pb}$ ages of $1.7-1.9 \mathrm{Ga}$. The possibility that the Chitrakoot and Jhamarkotra Formations are roughly contemporaneous offers significant comparisons between apatite distribution and microbial fabrics within the phosphatic stromatolites from the two formations. Even though the degree of preservation and the morphology of stromatolite columns differ between the two regions, the relationship between phosphate and stromatolites remains the same; in both regions, the distribution of phosphate is spatially confined to stromatolites of potential cyanobacterial and algal origin (e.g., Chauhan, 1979; Bengtson et al., 2009, 2017; Sallstedt et al., [submitted to Palaios]) indicating that oxygenic phototrophic biotas may have been key players in phosphorite formation in both of these areas. Indeed, the tufted filamentous or tubular fabrics in the Vindhyan stromatolites are very similar to those of the Aravalli, although fabrics are generally better preserved within the Vindhyan mats (e.g., Figures 8 and $11 \mathrm{~d}, \mathrm{e})$. Tufted morphologies and other microbial fabrics produced by filamentous bacteria have been described from ancient deposits (e.g., Buick, 1992; Sumner, 1997) as the results of gliding within filamentous communities (Shepard \& Sumner, 2010) and preservation through rapid mineralization. Vertical or near-vertical growth among filaments may also reflect a response to chemical or sedimentological influences within microbial mats (e.g. Stal, 2000; Jones et al., 2005; Shepard, Stork, Oberstadt, Armstrong, \& Sumner, 2008; Seong-Joo \& Golubic, 1999). The cyclic filamentous fabrics preserved in some of the mats with alternating vertical prostrate growth positions (Figure 8e,f) resemble the type of fabrics that can be seen in microbial hot spring environments and have been attributed to diel migration of filamentous cyanobacteria within microbial mats (e.g., Garcia-Pitchel et al., 1994; Konhauser, Jones, Phoenix, Ferris, \& Renaut, 2004; Konhauser et al., 2001; Stal, 2000). Curiously, these types of cyclic fabrics, while certainly important testimonies to the rapid preservation of microbes in the Vindhyan, are rather rare within the mats, perhaps indicating episodes of specific preservational conditions.

The presence of fossil-rich, kerogenous dark apatite laminae alternating with light, fossil-poor apatite layers shows that dispersed mat carbon was integrated within the Jankikund apatite stromatolite matrix in a cyclic fashion (e.g., Figure 6e,f). The lighter laminae mostly consist of diagenetically encrusting void-filling apatite, or fibrous apatite rims enclosing organic material (Krajewski, 1984; Sallstedt et al. [submitted to Palaios]). This could reflect a seasonal accretion of microbial mats in the Vindhyan, where periods of extensive organic biofilm growth and early apatite impregnation of microbial communities alternated with periods of non-growth and increased phosphatization of diagenetically degraded mat material (Gomez, Kah, Bartley, \& Astini, 2012; Konhauser et al., 2001).
While the Aravalli stromatolites have been subjected to lowgrade metamorphism, comparable to lower greenschist facies, many of the smaller stromatolites examined in this study show remarkably well-preserved filamentous microbial fabrics consistent with laminae formation by filamentous micro-organisms (e.g., Figures 3 and 4). Filament bundles assigned to algae, or possibly cyanobacteria, have previously been reported from the Jhamarkotra stromatolites by Chauhan (1979), and these are analogous to the filamentous fabrics and tufts reported here from the Jhamarkotra oncoid conical stromatolites (see e.g., Figure 11d). While the influence of slight metamorphism affected the overall directionality of many columnar stromatolites of the Jhamarkotra area, resulting in tilting of the columns in the direction of shear (Chauhan, 1979), the type of microfabrics found in smaller columns appears in many cases to have retained primary textural features (e.g., Figure 4a,b). The internal lamination and structure of Jhamarkotra stromatolite columns are testimonies of conical growth: Firstly, the Aravalli laminae are steeply convex, although slightly less so than some ancient Conophyton stromatolites (e.g., Kah, Bartley, \& Stagner, 2009). The filamentous mat fabrics have orientations parallel to lamination, a feature that is also described from modern conical microbialites (Walter, 1972; Walter et al., 1976). This filament orientation results in areas where the filamentous fabric seems to have an almost vertical direction along the sides of the columns (Figure $4 b, c$ ), which is the result of parallel alignment across a steeply inclined lamina rather than the result of actual vertical growth. At the apex, however, laminae often end with a tuft of vertical filaments (Figure $3 b, c$ ), as has also been reported from cone-forming microbialites from both modern (Walter et al., 1976) and ancient (Ruiji \& Leiming, 2011) locations.

The tendency for filamentous fabrics to form tufted bundles in the axial parts results in considerable thickening of laminations toward the middle of the structures (Komar, Raaben, \& Semikhatov, 1965; Walter et al., 1976). Not only do the crestal part of the Aravalli columns show a frequent tuft-like habit, they have a degree of porosity and disordered laminae that is somewhat similar to disordered crestal features from Archaean conical microbialites (e.g., Figure 3b in Bosak et al., 2009). Overall, we envision the Aravalli oncoid conical stromatolites to be roughly analogous in construction to the Neoproterozoic Siphonophycus-dominated conical domal-silicified stromatolites from the Jiudingshan and Niyuan Formations, South China (Ruiji \& Leiming, 2011). We note, however, that the Chinese stromatolites have a considerable preservational advantage with distinct individual filamentous fossils, as opposed to the more diagenetically affected mat fabrics present in the Aravalli cones, and they also appear to lack preserved fossil bubble-like structures as opposed to the Paleoproterozoic Indian examples. 
Our identification of tufted microbial fabrics, and especially of cone-like growth, in the phosphatic Aravalli stromatolites is significant from a biological as well as ecological perspective: Even though tufted mats, pinnacles and cones have been described from different types of environments on the modern Earth, such as hydrothermal (Walter, 1972; Walter et al., 1976) and lacustrine settings from Yellowstone National Park, Montana and Andros Island, Florida, the United States, as well as freshwater lakes in Antarctica (Andersen, Sumner, Hawes, Webster-Brown, \& McKay, 2011; Hawes, Sumner, Andersen, \& Mackey, 2011; Monty \& Hardie, 1976), a common factor is that all of these microbial fabrics were built by phototrophic motile filamentous bacteria of cyanobacterial nature, most commonly varying species of Phormidium, Lyngbya, or Scytonema (e.g., Flannery \& Walter, 2012; Monty \& Hardie, 1976; Walter, 1972; Walter et al., 1976). The accretion of conical stromatolites has been extensively studied, and it is generally believed that motile filamentous micro-organisms, presumably cyanobacteria, have been essential for cone formation (Bosak et al., 2009, 2010; Buick, 1992; Flannery \& Walter, 2012; Walter, 1972; Walter et al., 1976).

Walter et al. (1976) suggested the morphogenesis of cones to result from cyanobacterial motility, entanglement, and subsequent deflection of filaments on top of entangled clumps, presumably as a result of positive phototaxis (Flannery \& Walter, 2012; Walter, 1972; Walter et al., 1976). However, laboratory studies conducted with mat-forming bacteria isolated from both hot spring and lacustrine environments have shed light on the various mechanisms related to the constructions of filamentous tufts, pillars, cones, or clumps which are associated with the formation of cone-like microbialites (Shepard \& Sumner, 2010; Sim et al., 2012). These studies rather suggest that the deflective movement of filaments over entangled specimens or obstacles within a mat does not occur as a result of changing light intensities but rather happens irrespectively of irradiance. Instead, limitations of chemical species such as $\mathrm{O}_{2}$ or $\mathrm{CO}_{2}$ could potentially result in filaments deflecting upwards and ultimately ending up constructing microbial tufts, pillars, and, in the end, cones (Shepard et al., 2008; Sim et al., 2012). The formation of these types of morphologies would then rather reflect organismal responses to DIC, in the ambient environment, or possibly aerotaxis.

\subsection{Gas bubbles indicate photosynthetic activity}

Modern microbial mats are known to trap photosynthetically produced oxygen bubbles in zones of intense photosynthesis. The metabolism of phototrophic cyanobacteria can thus create a primary porosity within microbial mats (Bosak et al., 2009, 2010), which can even, at times, lead to ripping and detachment of the mat fabrics (Mata et al., 2012). Microbial mats represent small ecosystems in which primary production is nearly balanced by organic matter respiration by heterotrophic bacteria in lower layers, and so bubbles can also be formed by reducing gases such as $\mathrm{CH}_{4}$, or possibly $\mathrm{H}_{2}$ (Gerdes, Klenke, \& Noffke, 2000). However, in relatively undecayed laminae, and without other signals like highly

${ }^{13} \mathrm{C}$-depleted organic carbon indicating the presence of extensive methanotrophy within the mat, bubbles can be used as a signature for oxygen production (Bosak et al., 2009, 2010). The preservation of submillimeter- to millimeter-sized gas bubbles of photosynthetic origin has been described from ancient cone-shaped microbialites by Bosak et al. (2009). Both the Vindhyan and the Aravalli phosphatic stromatolites contain abundant well-preserved spherical to nearly spherical objects, empty or infilled with secondary dolomite, or, sometimes, silica-rich phases (Figures 4, 5, 6e,h, 8d and 10). In the Vindhyan, these structures are clustered within dark, organicrich mat laminae. While only sporadically (e.g., Figures $8 d$ and 10c), enmeshed by filamentous fabrics, these objects likely represent bubbles resulting from oxygenic photosynthesis within a viscous organic biofilm matrix. Their size as well as their nearly spherical shape is consistent with the structures described by Bosak et al. (2009) from Neoarchaean conical stromatolites in the Tumbiana Formation. The Vindhyan objects appear at times to have been slightly compressed, suggesting that they were stabilized by a flexible coating, such as EPS, which led to the formation of abundant foam-like fabrics (Figure 10a-c,f). The directed tubular extensions reported by Bengtson et al. (2009, Figure 3G) in Jankikund globules appear to have a direct counterpart in the tubes formed by rising bubbles in modern photosynthetic mats (Bosak et al., 2010, Figure 4). Significantly, the bubble-like features of the Vindhyan mats all occur within fine-grained in situ laminae and contribute to primary porosity.

In the Aravalli, the absence of body fossils puts all the more emphasis on interpreting other morphological characteristics. The abundant bubble-like structures that sometimes cluster around the apex, possibly in the spots of maximum photosynthesis, are similar to the fossil oxygen bubbles described by Bosak et al. (2009). The size of the bubbles in the Aravalli stromatolites ranges between $50 \mu \mathrm{m}$ and $500 \mu \mathrm{m}$, and the mean size of approximately $150-200 \mu \mathrm{m}$ is consistent with the most common and stable bubble sizes in the fossil record (e.g., Bosak et al., 2009). The connection between cone-like filamentous growth and fossil bubbles is significant, as it supports the interpretation of the Aravalli oncoid conical stromatolites as having been formed by motile filamentous and presumably cyanobacterial communities.

\subsection{Carbon isotopes and rhodophyte-like fossils highlight the significance of oxygen production in Vindhyan stromatolites}

The simple morphologies of filamentous and coccoid cyanobacteria make them difficult targets for taxonomical identification in the rock record, which is why the presence of complex eukaryotic fossils of probable red algal nature (e.g., Bengtson et al., 2017) embedded within the cyanobacteria-like filaments in the Vindhyan mats is significant. Because of their prominent multicellular and algae-like morphology, these fossils may be important in constraining the type of setting in which the Vindhyan stromatolites were deposited, and their presence in the mats highlight the oxygen-producing nature of the Vindhyan biota. Together with the tufted microbial fabrics produced 
by putative cyanobacterial fossils and the preservation of bubble-like objects in pristine mat laminae, these evidences together point toward a shallow setting where primary production was dominated by cyanobacterial and algal photosynthesis.

A bulk average $\delta^{13} \mathrm{C}_{\text {org }}$ value of $-30.43 \%$ of organic carbon within in the Vindhyan stromatolites (see Table S1) provides further support of Calvin cycle carbon fixation and the activity of oxygenic phototrophs (i.e., Johnston \& Fischer, 2012; Schidlowski, Hayes, \& Kaplan, 1983). As the Vindhyan isotopic values represent bulk carbon within the mats and have not been measured in situ on individual fossils, this value should be considered together with the other morphological factors suggesting an oxygen-producing setting. However, while we cannot exclude the possibility of a mixed carbon isotopic signal, the activity of, for example, methanogenic bacteria would have resulted in significantly lower carbon isotope fractionations of up to -40 to -60 \%o (Fischer et al., 2009; Hayes, 1994), suggesting a heavy influence
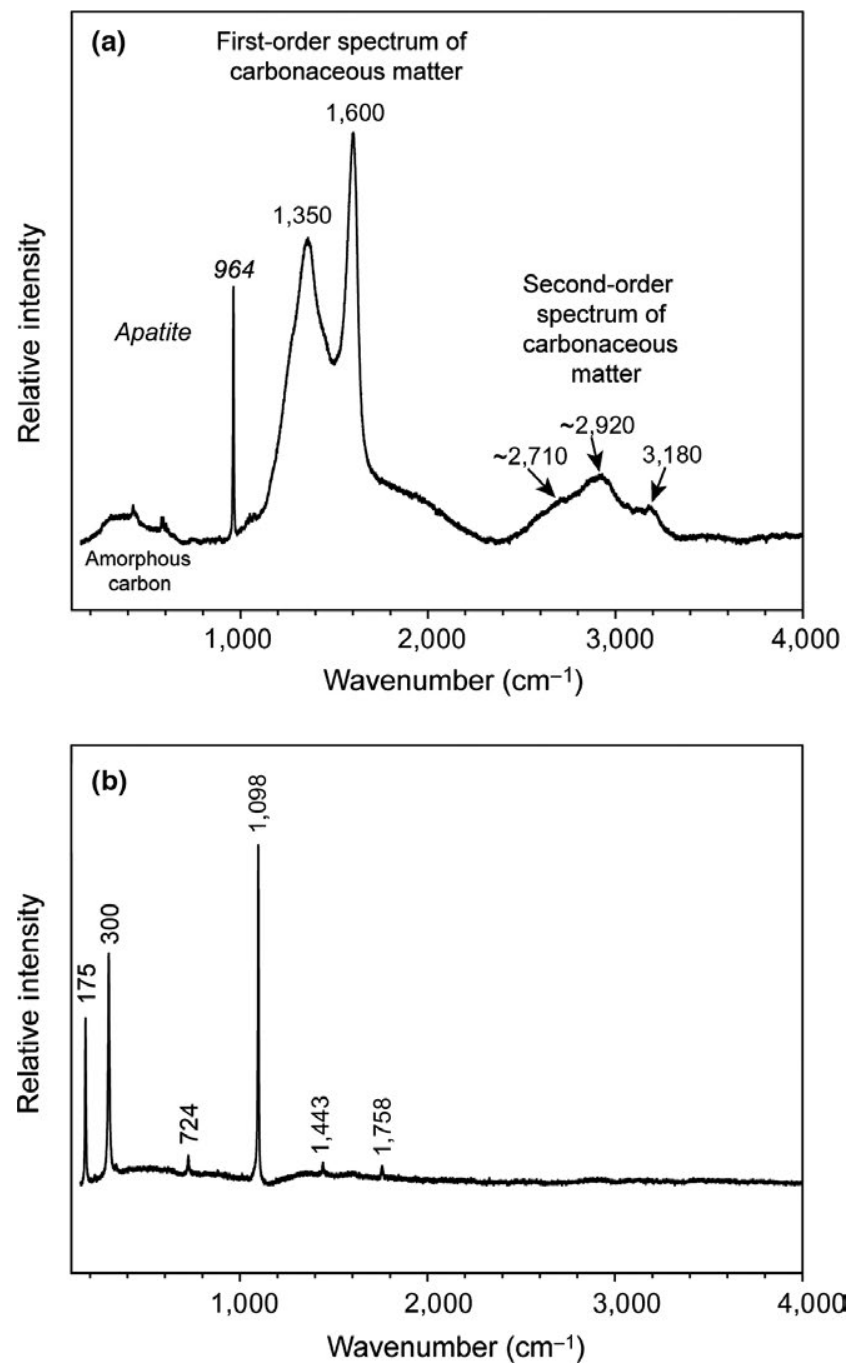

FIGURE 7 Raman spectra from Jankikund stromatolite. (a) Firstand second-order Raman spectra in the range of $100-4,000$ per $\mathrm{cm}^{2}$ from a dark apatite layer with kerogenous matter at 1,350 and 1,600. (b) Raman spectra from a dolomite layer. Note absence of kerogenous peaks at 1,350 and 1,600 , respectively of Calvin cycle metabolism on carbonaceous matter in the Vindhyan stromatolites.

\section{4 | Phosphogenesis associated with microbial communities}

Many studies from modern and fossil phosphogenic environments report similar associations between abundant microbial fabrics, fossils, and phosphate deposition (Bailey, Joye, Kalanetra, Flood, \& Corsetti, 2007; Bailey et al., 2013; Crosby, Bailey, \& Sharma, 2014; Lepland et al., 2014; Schulz \& Schulz, 2005; She et al., 2013; Soudry, 1987; Soudry \& Champetier, 1983). For example, several studies have focused on the presence and potential activity of sulfur-oxidizing bacteria (Bailey et al., 2013; Goldhammer, Brüchert, Ferdelman, \& Zabel, 2010; Schulz \& Schulz, 2005) in the formation of sedimentary phosphorites (Bailey et al., 2007; Lepland et al., 2014). Possible ironoxidizing bacteria have also been described from Jhamarkotra phosphorites (e.g., Crosby et al., 2014), indicating steep redox gradients within the Aravalli microbial mounds (Crosby et al., 2014; Papineau, Purohit, Fogel, \& Shields, 2013). The ability of sulfur and iron-oxidizing bacteria to store intracellular polyphosphate, polyP, represents a plausible mechanism for concentrating phosphate within the oxic zone (Bailey et al., 2013; Crosby et al., 2014; Goldhammer et al., 2010; Schulz \& Schulz, 2005). Chemolithotrophic bacteria harness the energy from hydrolysis of intracellularly stored polyP, and in conditions of high sulfide, or in oxygen-depleted waters, polyP may be released as orthophosphate and lead to supersaturation of apatite (Brock \& Schulz-Vogt, 2011; Goldhammer et al., 2010; Schulz \& Schulz, 2005). She et al. (2013), on the other hand, reported on the contribution of cyanobacteria to phosphatization of granular phosphorites from the South China Doushantuo Formation, highlighting the importance of apatite precipitation within the organic exopolymeric matrix of cyanobacterial communities to the accretion of granular phosphorites.

\subsection{Potential influence of phototrophs on apatite precipitation}

An important phosphate sink in marine non-upwelling zones is the precipitation and subsequent accumulation of authigenic apatite in sediments (Diaz et al., 2008; Ruttenberg \& Berner, 1993). As opposed to the specific environments commonly inhabited by sulfur-oxidizing bacteria, the Paleoproterozoic phosphatic stromatolites described herein seem to have been formed along a well-lit, relatively shallowwater carbonate platform, as indicated by the mineralogy, tufted cyanobacteria-like filaments, and conspicuous multicellular red algae (e.g., Bengtson et al., 2017). Laboratory studies (e.g., Diaz et al., 2008; Mukherjee, Chowdhury, \& Ray, 2015) show that modern oxygenic phototrophic microbial communities, for example cyanobacteria of Lyngbya type and diatoms, accumulate phosphate by internal polyP storage within their trichomes or frustules, indicating that cyanobacterial communities can be locally important in concentrating phosphate in shallow-water sedimentary environments. Cyanobacteria also contribute to diurnally fluctuating $\mathrm{pO}_{2}$ regimes within microbial 

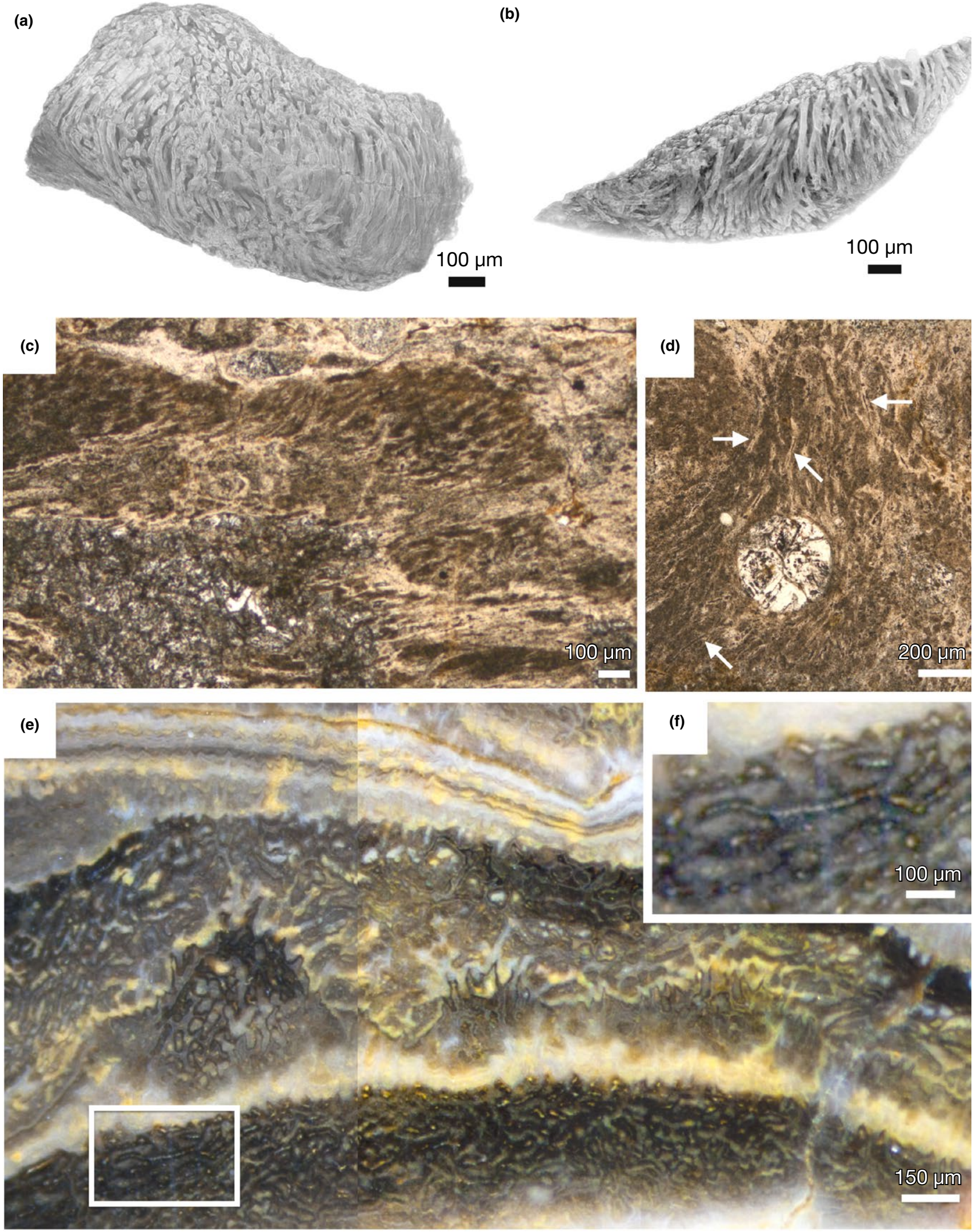

(b)

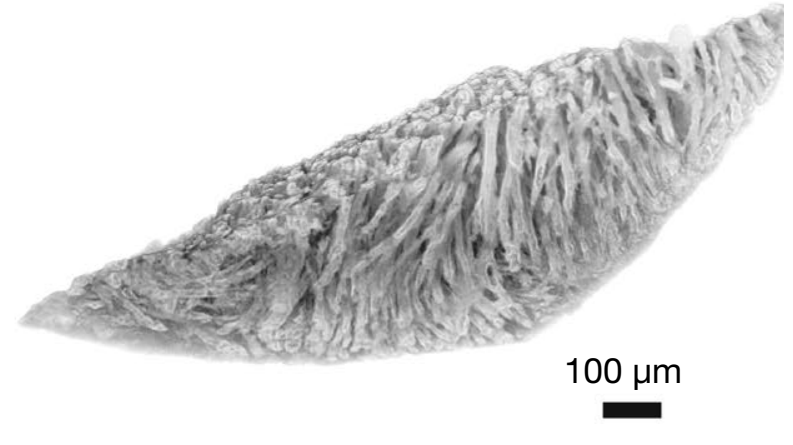

(d)

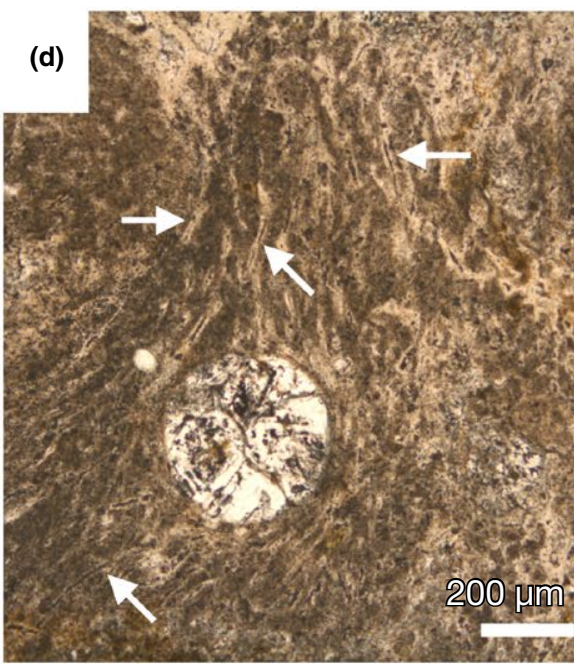

FIGURE 8 Filamentous stromatolitic fabrics from Jankikund. SrXTM (a, b), thin section (c, d), and polished surface section (e, f). (a, b) Partly translucent volume texture renderings showing tufted filament fabric. The fossils were obtained by acid maceration. (c) In situ filamentous fabric showing upright to slightly inclined growth. (d) Filaments (arrows) form a tuft around a globule within an apatite mat layer. (e) Alternating upright/prostrate filamentous fabrics. Upright filaments form tufts, and entangled filaments form a dense mass below and above the tufts. Frame indicates position of (f). (f) Enlargement of dense entangled filaments [Colour figure can be viewed at wileyonlinelibrary.com] 
mats, a feature that might be important for apatite precipitation, as it would help to establish steep local redox gradients, affecting the release of bioavailable phosphate within the mats. Diurnal fluctuating oxygen levels caused by cyanobacterial photosynthesis may also be significant for iron pumping, by which phosphate bound to iron oxyhydroxides can be released in periods and/or areas of low oxygen levels (Föllmi, 1996).
Furthermore, cyanobacteria and their EPS are generally well known to play a significant role in precipitation of many types of microbial mineral fabrics, especially that of $\mathrm{CaCO}_{3}$ (e.g., Arp et al., 2001; Dupraz \& Visscher, 2005; Merz, 1992). Cyanobacterial photosynthesis leads to a significant rise in ambient alkalinity following the uptake of $\mathrm{HCO}_{3}{ }^{-}$and subsequent release of $\mathrm{CO}_{3}{ }^{2-}$ by cyanobacterial trichomes, which, in turn, increase carbonate supersaturation (Arp et al., 2001).
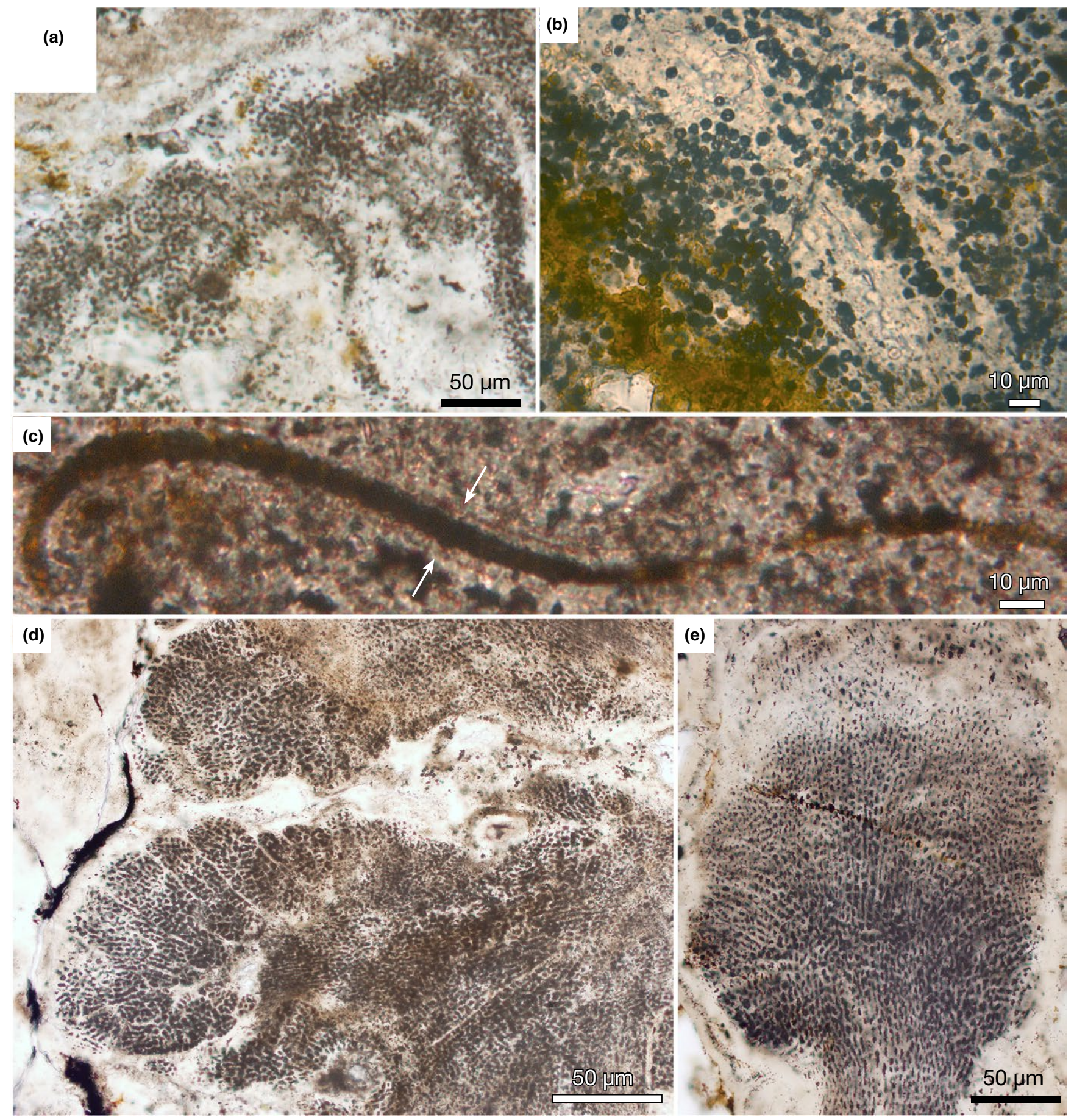

FIGURE 9 Microfossils and algae from Jankikund; thin sections. (a, b) Mat-building coccoids. (c) Single curved filament with phosphate rim (arrows). (d) Part of a thallus of probable red algae (Ramathallus lobatus) with cells arranged in finger-like extensions. Also figured in Bengtson et al. (2017), Figure 13. (e) Pseudoparenchymatous "cell-fountain" structure in a thallus of R. lobatus. Also figured in Bengtson et al. (2017), Figure 16A [Colour figure can be viewed at wileyonlinelibrary.com] 

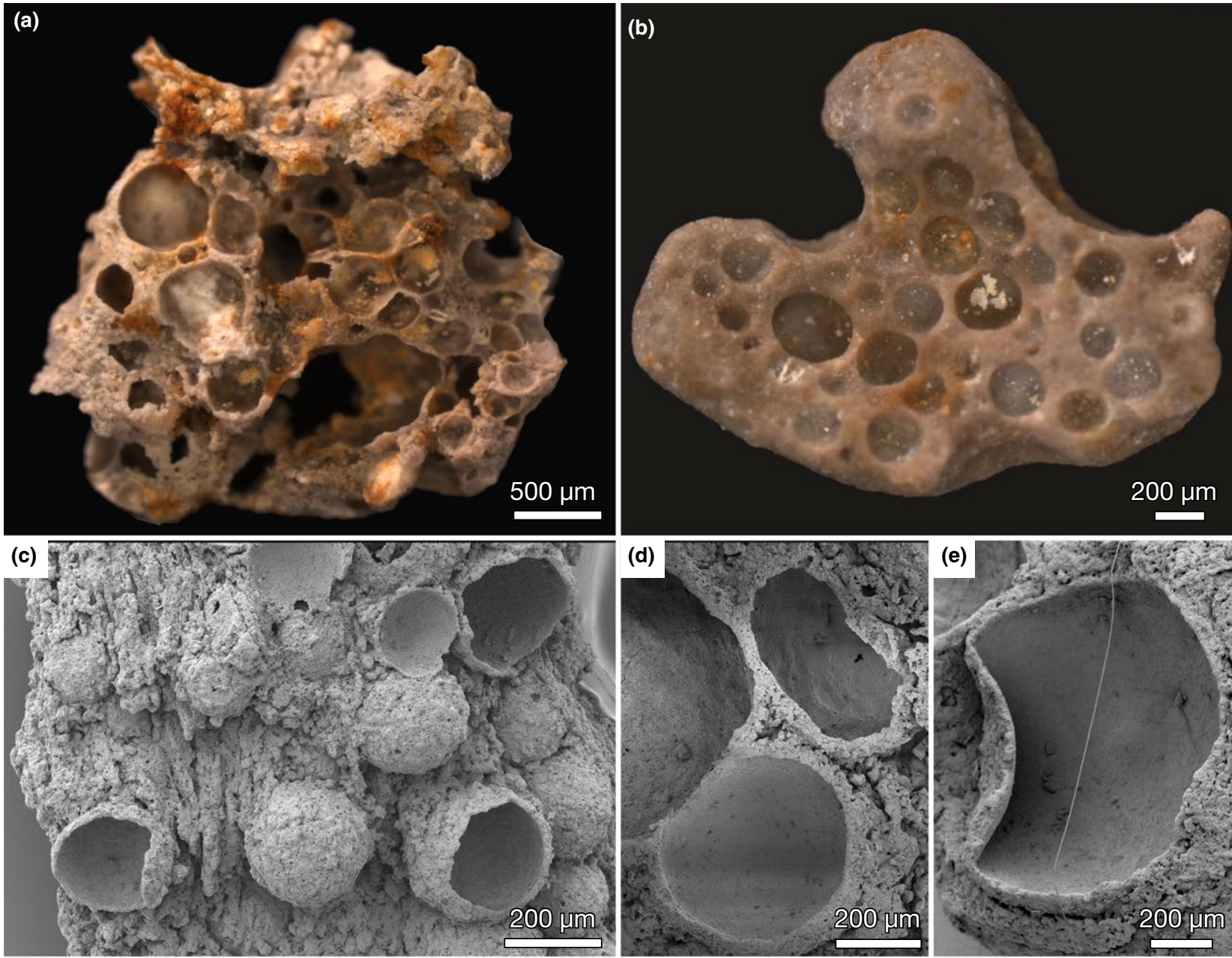

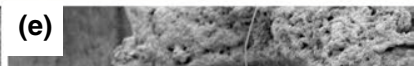

(f)

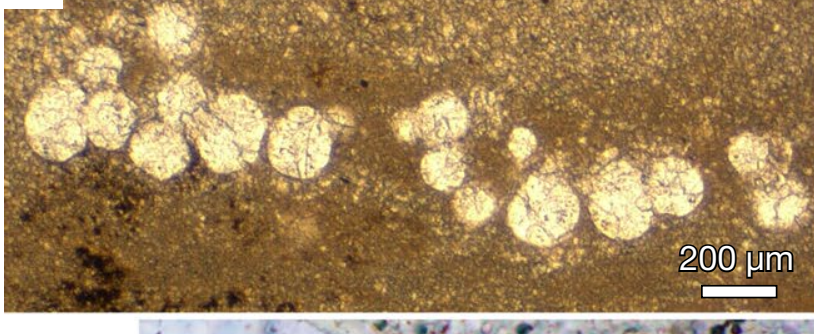

(g)

(i),$x_{2}$
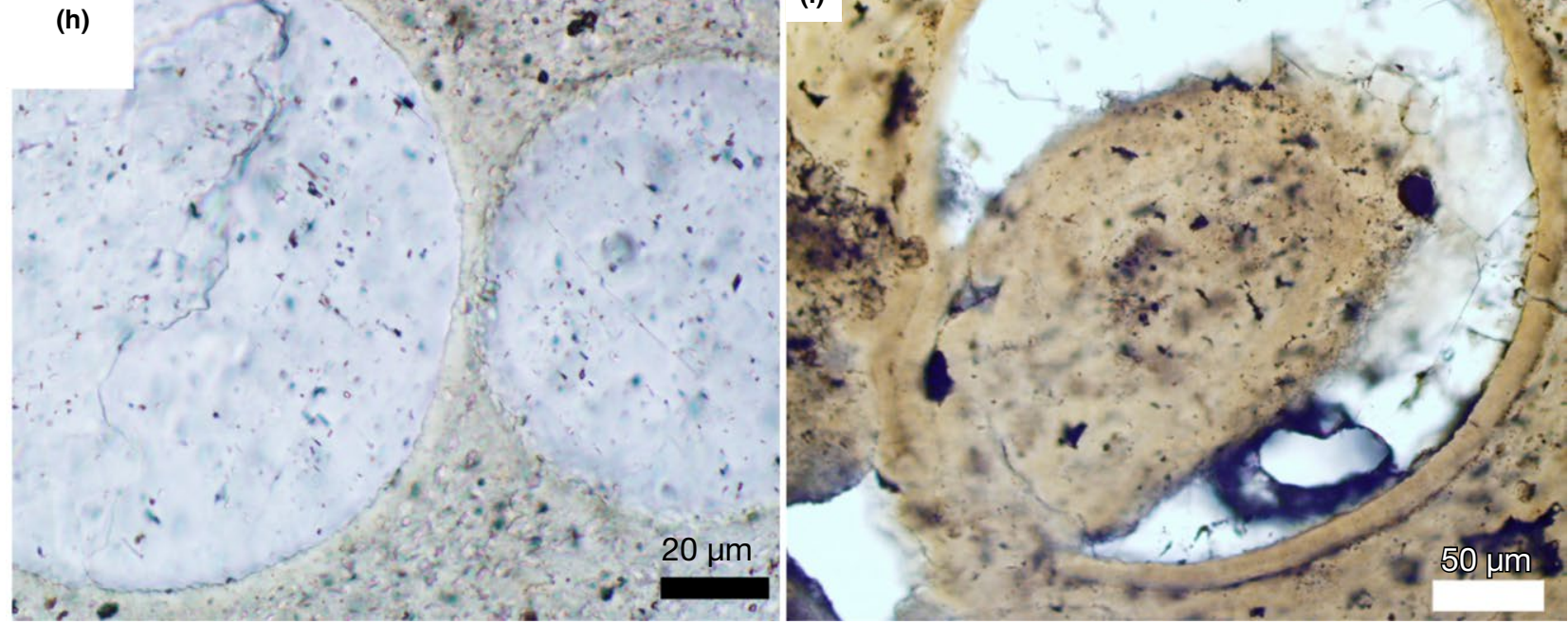
FIGURE 10 Globular structures interpreted as gas bubbles in cyanobacterial biomats from Jankikund stromatolites. Phosphatic clasts obtained by acid maceration (a-e) and thin sections of rock samples ( $\mathrm{f}-\mathrm{i})$. (a) Foamy fabric with slightly compressed, empty globules. (b) Wellrounded globules of varying size (c) SEM micrograph of hollow globules enmeshed in a filamentous fabric. Note granular external layer. SMNH S156414. From Bengtson et al. (2009), Figure 3A. (d, e) SEM micrographs of empty globules, slightly compressed. Note discontinuity of outer granular layer where globules meet (d) and evidence of former flexibility (e). (f, g) Globules infilled with dolomite, mostly concentrated to the darker apatite laminae. (h) Globules lined with void-filling apatite and infilled with dolomite. (i) Encrusting void-filling apatite internally lining a globule. Apatitic matter has entered the structure [Colour figure can be viewed at wileyonlinelibrary.com]
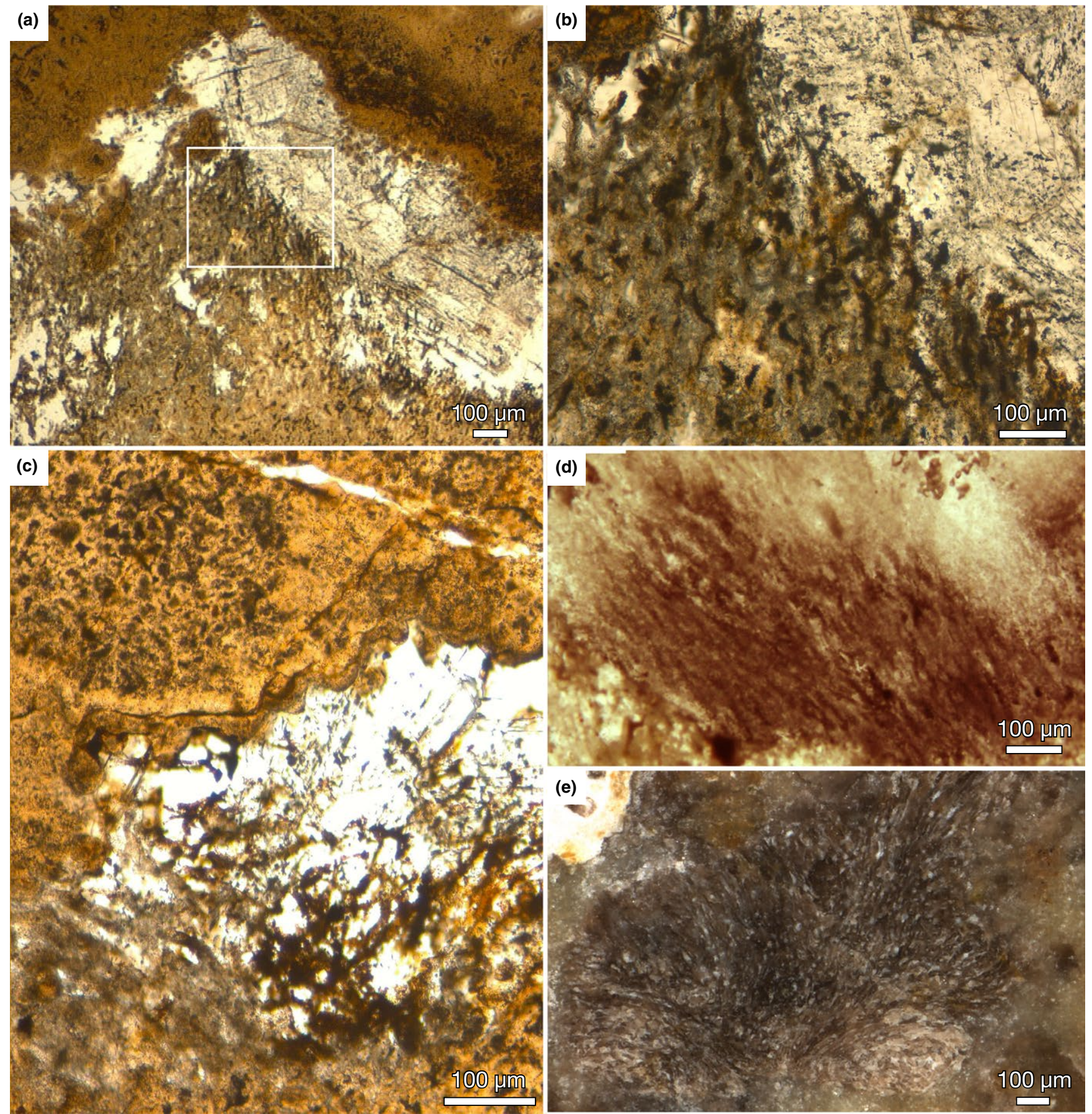

FIGURE 11 Filamentous structures with tufted growth in Jankikund (a-c, e) and Jhamarkotra (d) stromatolites. Thin sections. (a) Filaments associated with irregular fenestrae (white). Frame indicates position of (b). (b) Close-up of (a). (c) Filaments associated with irregular fenestrae (white) (d) Filamentous tuft, Jhamarkotra (e) Filamentous tuft, Jankikund [Colour figure can be viewed at wileyonlinelibrary.com] 
In a situation where abundant DIC acts as a $\mathrm{pH}$ buffer for the system, the activity of oxygenic photosynthesis may, in places where acidic functional groups within the EPS correspond to the geometry of calcite crystal nucleation, lead to calcite precipitation within the EPS biofilm matrix. Reversely, in $\mathrm{Ca}^{2+}$-rich hard water settings, which are more prone to changes in $\mathrm{pH}$, mineral precipitation can occur within or external to cyanobacterial sheaths, creating microbial tubular carbonate fabrics similar to those of Girvanella-like microfossils (Arp et al., 2001; Merz, 1992). This has been observed in modern environments, and microbially (especially cyanobacterially) induced or influenced mineralization was a significant process leading to the accretion of ancient microbialites (e.g., Dupraz et al., 2004; Grotzinger \& Knoll, 1999; Riding, 2000).

While apatite is a more complex mineral than calcite in terms of elemental composition, the two share many properties, for example $\mathrm{Ca}^{2+}$ as a main cation (Gulbrandsen, 1969). Thus, calcite and apatite are often found in close association in natural systems. In the Vindhyan and Aravalli stromatolites, this is illustrated by the alternating precipitation of calcite and apatite within some stromatolites, suggesting the presence in these systems of closely related $\mathrm{pH}$ - and saturationcontrolled precipitation switches (Figure 6h; Briggs \& Wilby, 1996).

Normally, however, the ratio in the marine environment of phosphate to carbonate ions is extremely low, which leads to the preferential precipitation of calcite in favor of apatite (Gulbrandsen, 1969). Thus, for apatite to precipitate, an extensive external source of phosphate is needed (see review by Papineau, 2010) along with a mechanism to concentrate $P$ locally in order to increase apatite supersaturation, for example within a microbial mat. In the case of phosphogenesis within the Vindhyan and Aravalli stromatolites, we suggest a scenario where early diagenetic apatite precipitates as a consequence of oxygenic cyanobacterial and algal concentration of phosphate from a significant outside phosphate source, for example related to pulses of increased continental weathering (e.g., Papineau, 2010). It is possible that rifting within a tectonically active intracontinental basin could lead to local upwelling of nutrient-rich water within an otherwise shallow carbonate plateau, thus providing a significant source of phosphate to the system (cf Figure 6d). This in turn would result in increased primary productivity and promote local precipitation of apatite within the shallow-water cyanobacterial and algal mats. In this type of setting, we envision that photosynthesizing stromatolite communities provide a local control on fluctuating $\mathrm{O}_{2}$ regimes, leading to the formation of steep redox gradients within microbial mat pore spaces. This might effectively induce the release of microbially stored polyP in anoxic parts of the mats, thus promoting the formation of apatite-rich stromatolites in the shallow-water Proterozoic Indian basins.

\section{5 | CONCLUSIONS}

The identification of phototaxy in the rock record as a mean to constrain cyanobacterial evolution is ultimately difficult. While microbially derived features in sedimentary rock may provide clues to the nature of fossil organisms, these do not by themselves constitute evidence for the presence of oxygenic photosynthesis. Our results show that a combination of morphological and geochemical methods may provide convincing signals of microbial metabolism in ancient phosphatic stromatolites. In particular, the combination of a synsedimentary fossil biota containing cyanobacterial and algal morphotypes, together with $\delta^{13} \mathrm{C}_{\text {org }}$ values that can be derived from Rubisco-1 type metabolisms and the presence of abundant fossil bubbles within undecayed in situ-precipitated mats, provides evidence for the activity of oxygenic phototrophs in the $1.6 \mathrm{Ga}$ stromatolitic Vindhyan phosphorites. Similarly, the presence of well-preserved nearly spherical bubbles enmeshed within microbial tufted fabrics in the oncoid conical Aravalli stromatolites suggests that motile cyanobacteria were associated with phosphate mineralization also at Jhamarkotra. The distribution of phosphate in the Vindhyan and Aravalli follows a similar pattern, with apatite clearly associated with biogenic stromatolite columns, rims, and intercolumnar clasts. These similarities may prove particularly significant in light of the new geochronological dating of the AravalliJhamarkotra Formation as roughly contemporary with Lower Vindhyan Jankikund strata. If this dating is correct, it would indicate the occurrence of a much larger phosphogenic event at the transition between the Paleo- and the Mesoproterozoic than hitherto understood. Previous studies have, with a few exceptions, focused on the role of chemolithotrophic bacteria in phosphorite formation. This study suggests that oxygenic phototrophic biotas may have played a larger role in the construction of ancient shallow-water phosphorites than previously recognized.

\section{ACKNOWLEDGMENTS}

The authors wish to thank R. Azmi, A. Sarkar, P. Kothari, P. Chakraborty, M. Bera, A. Samanta, and A. Singh for information and guidance in the field. We also thank $\mathrm{V}$. Belivanova for assistance in the field and laboratories. Microtomography was carried out at the Swiss Light Source (SLS), Paul Scherrer Institute (PSI), as a joint project with P.C.J. Donoghue and Else Marie Friis. M. Stampanoni and F. Marone are thanked for experimental setup and assistance at the TOMCAT beamline. M. Ahlbom is acknowledged for help with ESEM-EDS analysis and E. Hammarlund assisted with stable isotope analysis at the University of Southern Denmark (SDU). This research was funded by a Ph.D. grant to T. Sallstedt, the Swedish Research Council (grants 2010-3929 and 2013-4290 to S. Bengtson), and the Danish National Research Foundation (grant DNRF53 to D. Canfield). We wish to acknowledge the Jhamarkotra mine authority, Rajasthan, for granting us field visit. All co-authors are aware of and agree to the publication of this manuscript and declare no conflict of interest. Helpful suggestions from three anonymous reviewers significantly improved the final version of the manuscript.

\section{ORCID}

T. Sallstedt iD http://orcid.org/0000-0002-9541-7866 


\section{REFERENCES}

Alexandre, G., Greer-Phillips, S., \& Zhulin, I. B. (2004). Ecological role of energy taxis in microorganisms. FEMS Microbiology Reviews, 28, 113-126. https://doi.org/10.1016/j.femsre.2003.10.003

Allwood, A. C., Walter, M. R., Burch, I. W., \& Kamber, B. S. (2007). 3.43 billion-year-old stromatolite reef from the Pilbara Craton of Western Australia: Ecosystem-scale insights to early life on Earth. Precambrian Research, 158, 189-227.

Allwood, A. C., Walter, M. R., Kamber, B. S., Marshall, C. P., \& Burch, I. W. (2006). Stromatolite reef from the Early Archaean era of Australia. Nature, 441, 714-718. https://doi.org/10.1038/nature04764

Alvaro, J. J., \& Clausen, S. (2010). Morphology and ultrastructure of epilithic versus cryptic microbial growth in lower Cambrian phosphorites from the Montagne Noire, France. Geobiology, 8, 89-100. https://doi. $\operatorname{org} / 10.1111 / \mathrm{j} .1472-4669.2009 .00229 . x$

Andersen, D. T., Sumner, D. Y., Hawes, I., Webster-Brown, J., \& McKay, C. (2011). Discovery of large conical stromatolites in Lake Untersee, Antarctica. Geobiology, 9, 280-293. https://doi. org/10.1111/j.1472-4669.2011.00279.x

Arp, G., Hofman, J., \& Reitner, J. (1998). Microbial fabric formation in spring mounds ("microbialites") of alkaline salt lakes in the Badain Jaran Sand Sea, PR China. Palaios, 13, 581-592. https://doi.org/10.2307/3515349

Arp, G., Reimer, A., \& Reitner, J. (2001). Photosynthesis-induced biofilm calcification and calcium concentrations in Phanerozoic oceans. Science, 292, 1701-1704. https://doi.org/10.1126/science.1057204

Bailey, J. V., Corsetti, F. A., Greene, S. E., Crosby, C. H., Liu, P., \& Orphan, V. J. (2013). Filamentous sulfur bacteria preserved in modern and ancient phosphatic sediments: Implications for the role of oxygen and bacteria in phosphogenesis. Geobiology, 11, 397-405. https://doi.org/10.1111/ gbi.12046

Bailey, J. V., Joye, S. B., Kalanetra, K. M., Flood, B. E., \& Corsetti, F. A. (2007). Evidence of giant sulphur bacteria in neoproterozoic phosphorites. Nature, 445, 198-200. https://doi.org/10.1038/nature05457

Banerjee, D. M. (1971). Precambrian stromatolitic phosphorites of Udaipur, Rajasthan, India. Geological Society of America Bulletin, 82, 2319-2330. https://doi.org/10.1130/0016-7606(1971)82[2319:PSPOUR]2.0.CO;2

Batchelor, M. T., Burne, R. V., Henry, B. I., \& Jackson, M. J. (2004). A case for biotic morphogenesis of coniform stromatolites. Physica A, 337, 319-326. https://doi.org/10.1016/j.physa.2004.01.065

Baumgartner, L. K., Spear, J. R., Buckley, D. H., Pace, N. R., Reid, R. P., Dupraz, C., \& Visscher, P. T. (2009). Microbial diversity in modern marine stromatolites, Highborne Cay, Bahamas. Environmental Microbiology, 11(10), 2710-2719. https://doi. org/10.1111/j.1462-2920.2009.01998.x

Bengtson, B., Belivanova, V., Rasmussen, B., \& Whitehouse, M. (2009). The controversial "Cambrian" fossils of the Vindhyan are real but more than a billion years older. Proceedings of the National Academy of Sciences, 106, 7729-7734. https://doi.org/10.1073/pnas.0812460106

Bengtson, S., Sallstedt, T., Belivanova, V., \& Whitehouse, M. (2017). Threedimensional preservation of cellular and subcellular structures suggests 1.6 billion-year-old crown-group red algae. PLoS Biology, 15, 1-38.

Bosak, T., Busch, J. W. M., Flynn, M. R., Liang, B., Ono, S., Petroff, A. P., \& Sim, M. S. (2010). Formation and stability of oxygen-rich bubbles that shape photosynthetic mats. Geobiology, 8, 45-55. https://doi. org/10.1111/(ISSN)1472-4669

Bosak, T., Liang, B., Sim, M. S., \& Petroff, A. P. (2009). Morphological record of oxygenic photosynthesis in conical stromatolites. PNAS, 106, 10939-10943. https://doi.org/10.1073/pnas.0900885106

Bose, P. K., Sarkar, S., Chakrabarty, S., \& Banerjee, S. (2001). Overview of the Meso- Neoproterozoic evolution of the Vindhyan basin, central India. Sedimentary Geology, 141, 395-419. https://doi.org/10.1016/ S0037-0738(01)00084-7

Briggs, D. E. G., \& Wilby, P. R. (1996). The role of the calcium carbonatecalcium phosphate switch in the mineralization of soft-bodied fossils.
Journal of the Geological Society, London, 153, 665-668. https://doi. org/10.1144/gsjgs.153.5.0665

Brock, J., \& Schulz-Vogt, H. N. (2011). Sulfide induces phosphate release from polyphosphate in cultures of a marine Beggiatoa strain. The ISME Journal, 5, 497-506. https://doi.org/10.1038/ismej.2010.135

Buick, R. (1992). The antiquity of oxygenic photosynthesis: Evidence from stromatolites in sulphate-deficient Archaean lakes. Science, 255, 7477. https://doi.org/10.1126/science.11536492

Burne, R. V., \& Moore, L. S. (1987). Microbialites: Organosedimentary deposits of benthic microbial communities. Palaios, 2, 241-254. https:// doi.org/10.2307/3514674

Canfield, D. E., \& Teske, A. (1996). Late Proterozoic rise in atmospheric oxygen concentration inferred from phylogenetic and sulphur-isotope studies. Nature, 382, 127-132. https://doi.org/10.1038/382127a0

Chakraborty, C. (2006). Proterozoic intracontinental basin: The Vindhyan example. Journal of Earth System Science, 115, 3-22. https://doi. org/10.1007/BF02703022

Chauhan, D. S. (1979). Phosphate-bearing stromatolites of the Precambrian Aravalli phosphorite deposits of the Udaipur region, their environmental significance and genesis of phosphorite. Precambrian Research, 8 , 95-126. https://doi.org/10.1016/0301-9268(79)90040-8

Crosby, C. H., Bailey, J. V., \& Sharma, M. (2014). Fossil evidence of ironoxidizing chemolithotrophy linked to phosphogenesis in the wake of the great oxidation event. Geology, 42, 1015-1018. https://doi. org/10.1130/G35922.1

Diaz, J., Ingall, E., Benitez-Nelson, C., Paterson, D., De Jonge, M. D., Mcnulty, I., \& Brandes, J. A. (2008). Marine polyphosphate: A key player in geologic phosphorus sequestration. Science, 320, 652-655. https:// doi.org/10.1126/science.1151751

Dupraz, C., Fowler, A., Tobias, C., \& Visscher, P. T. (2013). Stromatolitic knobs in Storr's Lake (San Salvador, Bahamas): A model system for formation and alteration of laminae. Geobiology, 11, 527-548. https://doi. org/10.1111/gbi.12063

Dupraz, C., \& Visscher, P. T. (2005). Microbial lithification in marine stromatolites and hypersaline mats. Trends in Microbiology, 13, 429-438. https://doi.org/10.1016/j.tim.2005.07.008

Dupraz, C., Visscher, P. T., Baumgartner, L. K., \& Reid, R. P. (2004). Microbemineral interactions: Early $\mathrm{CaCO}_{3}$ precipitation in a recent hypersaline lake (Eleuthera Islands, Bahamas). Sedimentology, 51, 745-765. https:// doi.org/10.1111/j.1365-3091.2004.00649.x

Fedonkin, M. A. (2003). The origin of the Metazoa in the light of the Proterozoic fossil record. Paleontological Research, 1, 9-41. https://doi. org/10.2517/prpsj.7.9

Fenchel, T., \& Kuhl, M. (2000). Artificial cyanobacterial mats: Growth, structure, and vertical zonation patterns. Microbial Ecology, 40, 85-93.

Fischer, W. W., Schroeder, S., Lacassie, J. P., Beukes, N. J., Goldberg, T., Strauss, H., ... Knoll, A. H. (2009). Isotopic constraints on the Late Archean carbon cycle from the Transvaal Supergroup along the western margin of the Kaapvaal Craton, South Africa. Precambrian Research, 169, 15-27. https://doi.org/10.1016/j.precamres.2008.10.010

Flannery, D. T., \& Walter, M. R. (2012). Archaean tufted microbial mats and the Great Oxidation Event: New insight into an ancient problem. Australian Journal of Earth Sciences, 59, 1-11. https://doi.org/10.1080/ 08120099.2011.607849

Föllmi, K. B. (1996). The phosphorus cycle, phosphogenesis and marine phosphate-rich deposits. Earth-Science Reviews, 40, 55-124. https:// doi.org/10.1016/0012-8252(95)00049-6

Garcia-Pitchel, F., Mechling, M., \& Castenholz, R. W. (1994). Diel migration of microorganisms within a benthic, hypersaline mat community. Applied and Environmental Microbiology, 60, 1500-1511.

Gerdes, G., Klenke, T., \& Noffke, N. (2000). Microbial signatures in peritidal siliciclastic sediments: A catalogue. Sedimentology, 47, 279-308.

Goldhammer, T., Brüchert, V., Ferdelman, T. G., \& Zabel, M. (2010). Microbial sequestration of phosphorus in anoxic upwelling sediments. Nature Geoscience, 3, 557-561. https://doi.org/10.1038/ngeo913 
Gomez, F. J., Kah, L. C., Bartley, J. K., \& Astini, A. (2012). Microbialites in a high-altitude Andean lake: Multiple controls on carbonate precipitation and lamina accretion. Palaios, 29, 233-249.

Grotzinger, J. P., \& Knoll, A. H. (1999). Stromatolites in Precambrian carbonates: Evolutionary mileposts or environmental dipsticks? Annual Review of Earth and Planetary Sciences, 27, 313-358. https://doi.org/10.1146/ annurev.earth.27.1.313

Guido, D. M., \& Campbell, K. A. (2014). A large and complete Jurasic geothermal field at Claudia, Deseado Massif, Santa Cruz, Argentina. Journal of Volcanology and Geothermal Research, 275, 61-70. https:// doi.org/10.1016/j.jvolgeores.2014.02.013

Gulbrandsen, R. A. (1969). Physical and chemical factors in the formation of marine apatite. Economic Geology, 64, 365-382. https://doi. org/10.2113/gsecongeo.64.4.365

Harries, P. J. (2009). Epeiric seas: a continental extension of shelf biotas. In: Earth System: history and natural variability IV, Encyclopedia of Life Support Systems (EOLSS).

Hawes, I., Sumner, D. Y., Andersen, D. T., \& Mackey, T. J. (2011). Legacies of recent environmental change in the benthic communities of Lake Joyce, a perennially ice-covered Antarctic lake. Geobiology, 9, 394-410. https://doi.org/10.1111/j.1472-4669.2011.00289.x

Hayes, J. M. (1994). Global methanotrophy at the Archean-Proterozoic transition. In S. Bengston (Ed.), Early life on earth, 84 (pp. 200-236). New York, NY: Columbia University Press.

Hoiczyk, E. (2000). Gliding motility in cyanobacteria: Observations and possible explanations. Archives of Microbiology, 174, 11-17. https://doi. org/10.1007/s002030000187

Holland, H. D. (2002). Volcanic gases, black smokers, and the Great Oxidation Event. Geochimica et Cosmochimica Acta, 66, 3811-3826. https://doi.org/10.1016/S0016-7037(02)00950-X

Holland, H. D. (2006). The oxygenation of the atmosphere and oceans. Philosophical Transactions of the Royal Society B, 361, 903-915. https:// doi.org/10.1098/rstb.2006.1838

Jeppsson, L., Fredholm, D., \& Mattiasson, B. (1985). Acetic acid and phosphatic fossils - a warning. Journal of Paleontology, 59, 952-956.

Johnston, D. T., \& Fischer, W. W. (2012). Stable isotope geobiology. In A. H. Knoll, D. E. Canfield \& K. O. Konhauser (Eds.), Fundamentals of geobiology, 14 (pp. 250-268). Oxford, UK: Blackwell Publishing Ltd. https:// doi.org/10.1002/9781118280874.ch14

Jones, B., Renaut, R. W., \& Konhauser, K. O. (2005). Genesis of large siliceous stromatolites at Frying Pan Lake, Waimangy geothermal field, North Island, New Zealand. Sedimentology, 52, 1229-1252.

Joshi, D., Azmi, R. J., \& Srivastava, S. S. (2006). Earliest Cambrian calcareous skeletal algae from Tirohan Dolomite, Chitrakoot, Central India: A new age constraint for the Lower Vindhyan. Gondwana Geological Magazine, 21, 73-82.

Kah, L. C., Bartley, J. K., \& Stagner, A. F. (2009). Reinterpreting a Proterozoic enigma: Conophyton-Jacutophyton stromatolites of the Mesoproterozoic Atar Group, Mauritania. International Association of Sedimentologists. Special Publications, 41, 277-295.

Knoll, A. H., Wörndle, S., \& Kah, L. (2013). Covariance of microfossil assemblages and microbialite textures across an upper Mesoproterozoic carbonate platform. Palaios, 28, 453-470. https://doi.org/10.2110/ palo.2013.p13-005r

Komar, V. A., Raaben, M. E., \& Semikhatov, M. A. (1965). Conophytons in the Riphean of the URSS and their stratigraphic importance. Akademii Nauk SSSR Geology Institue Trudy, 131, 5-72.

Konhauser, K. O., Jones, B., Phoenix, V. R., Ferris, G., \& Renaut, R. W. (2004). The microbial role in hot spring silicification. Ambio, 33, 552558. https://doi.org/10.1579/0044-7447-33.8.552

Konhauser, K. O., Phoenix, V. R., Botrell, S. H., Asams, D. G., \& Head, I. M. (2001). Microbial silica interactions in Icelandic hot spring sinter: Possible analogues for some Precambrian siliceous stromatolites. Sedimentology, 48, 415-433. https://doi.org/10.1046/j.1365-3091. 2001.00372.x
Krajewski, K. P. (1984). Early diagenetic phosphate cements in the Albian condensed glauconitic limestone of the Tatra Mountains, Western Carpathians. Sedimentology, 31, 443-470. https://doi. org/10.1111/j.1365-3091.1984.tb01812.x

Krajewski, K. P. (2011). Phosphatic microbialites in the Triassic phosphogenic facies of Svalbard. In S Joseph (Ed.), STROMATOLITES: Interaction of microbes with sediments. Springer, pp. 187-222.

Lepland, A., Joosu, L., Kirsimäe, K., Prave, A. R., Romashkin, A. E., Crne, A. E., ... Schreiber, A. (2014). Potential influence of sulphur bacteria on Palaeoproterozoic phosphogenesis. Nature Geoscience, 7, 20-24.

Love, F. G., Simmons, G. M. Jr, Parker, B. C., Wharton, R. A. Jr, \& Seaburg, K. G. (1983). Modern conophyton-like microbial mats discovered in Lake Vanda, Antarctica. Geomicrobiology Journal, 3, 33-48. https://doi. org $/ 10.1080 / 01490458309377782$

Lyons, T. W., Reinhard, C. T., \& Planavsky, N. J. (2014). The rise of oxygen in Earth's early ocean and atmosphere. Nature, 506, 307-315. https://doi. org/10.1038/nature13068

Marone, F., \& Stampanoni, M. (2012). Regridding reconstruction algorithm for real-time tomographic imaging. Journal of Synchrotron Radiation, 19, 1029-1037. https://doi.org/10.1107/S0909049512032864

Mata, S. A., Harwood, C. L., Corsetti, F. A., Stork, N. J., Eilers, K., Berelson, W. M., \& Spear, J. R. (2012). Influence of gas production and filament orientation on stromatolite microfabric. Palaios, 27, 206-219. https:// doi.org/10.2110/palo.2011.p11-088r

McKenzie, N. R., Hughes, N. C., Myrow, P. M., Banerjee, D. M., Deb, M., \& Planavsky, N. J. (2013). New age constraints on the Proterozoic Aravalli Delhi successions of central India and their implications. Precambrian Research, 238, 120-128. https://doi.org/10.1016/j. precamres.2013.10.006

McKenzie, N. R., Hughes, N. C., Myrow, P. M., Banerjee, D. M., Deb, M., Planavsky, N. J. (2014). Reply to comment on "New age constraints on the Proterozoic Aravalli Delhi successions of central India and their implications" by Melezhik et al.. Precambrian Research, 246, 371-372. https://doi.org/10.1016/j.precamres.2014.03.005

Melezhik, V. A., Purohit, R., Papineau, D. (2014). Comment on "New age constraints on the Proterozoic Aravalli Delhi successions of central India and their implications" by McKenzie et al.. Precambrian Research, 246, 319-320. https://doi.org/10.1016/j.precamres.2014.03.018

Merz, M. (1992). The biology of carbonate precipitation by cyanobacteria. Facies, 26, 81-102. https://doi.org/10.1007/BF02539795

Monty, C. L. V., \& Hardie, L. A. (1976). The geological significance of the freshwater blue-green algal calcareous marsh. In M. R. Walter (Ed.), Stromatolites, developments in sedimentology (pp. 447-477). Amsterdam, Netherlands: Elsevier.

Mukherjee, C., Chowdhury, R., \& Ray, K. (2015). Phosphorus recycling from an unexplored source by polyphosphate accumulating microalgae and cyanobacteria-a step to phosphorus security in agriculture. Frontiers in Microbiology, 6, 1421.

Papineau, D. (2010). Global biogeochemical changes at both ends of the Proterozoic: Insights from phosphorites. Astrobiology, 10, 1-17.

Papineau, D., De Gregorio, B., Fearns, S., Kilcoyne, D., Mcmahon, G., Purohit, R., \& Fogel, M. (2016). Nanoscale petrographic and geochemical insights on the origin of the Palaeoproterozoic stromatolitic phosphorites from Aravalli Supergroup, India. Geobiology, 14, 3-32. https:// doi.org/10.1111/gbi.12164

Papineau, D., Purohit, R., Fogel, M. L., \& Shields, G. A. (2013). High phosphate availability as a possible cause for massive cyanobacterial production of oxygen in the Proterozoic atmosphere. Earth and Planetary Science Letters, 362, 225-236. https://doi.org/10.1016/j. epsl.2012.11.050

Papineau, D., Purohit, R., Goldberg, T., Pi, D., Shields, G. A., Bhu, H., ... Fogel, M. L. (2009). High primary productivity and nitrogen cycling after the Paleoproterozoic phosphogenic event in the Aravalli Supergroup, India. Precambrian Research, 171, 37-56. https://doi.org/10.1016/j. precamres.2009.03.005 
Reid, R. P., Visscher, P. T., Decho, A. W., Stolz, J. F., Bebout, B. M., Dupraz, C. D., ... DesMarais, D. J. (2000). The role of microbes in accretion, lamination and early lithification of modern marine stromatolites. Nature, 406 , 989-992. https://doi.org/10.1038/35023158

Riding, R. (2000). Microbial carbonates: The geological record of calcified bacterial-algal mats and biofilms. Sedimentology, 47, 179-214. https:// doi.org/10.1046/j.1365-3091.2000.00003.x

Roy, A. B., \& Paliwal, B. S. (1981). Evolution of lower Proterozoic epicontinental deposits: Stromatolite-bearing Aravalli rocks of Udaipur, Rajasthan, India. Precambrian Research, 14, 49-74. https://doi. org/10.1016/0301-9268(81)90035-8

Ruiji, C., \& Leiming, Y. (2011). Microbiota and microbial mats within ancient stromatolites in South China. In V. C. Tewari \& J. Seckbach (Eds.), STROMATOLITES: Interaction of microbes with sediments, cellular origin, life in extreme habitats and astrobiology, 18 (pp. 65-86). Berlin, Germany: Springer. https://doi.org/10.1007/978-94-007-0397-1

Ruttenberg, K. C., \& Berner, R. A. (1993). Authigenic apatite formation and burial in sediments from non-upwelling, continental margin environments. Geochimica et Cosmochimica Acta, 57, 991-1007. https://doi. org/10.1016/0016-7037(93)90035-U

Sallstedt, T., Bengtson, S., Broman, C., Crill, P. M., \& Canfield, D. E. (2017). Biofilm structure in $1.6 \mathrm{Ga}$ phosphatic stromatolites from the Vindhyan supergroup, central India. Manuscript submitted to PALAIOS.

Schidlowski, M., Hayes, J. M., \& Kaplan, I. R. (1983). Isotopic inferences of ancient biochemistries: Carbon, sulfur, hydrogen, and nitrogen. In J. W. Schopf (Ed.), Earth's earliest biosphere, its origin and evolution (pp. 149-186). Princeton, NJ: Princeton UP.

Schirrmeister, B. E., Antonelli, A., \& Bagheri, H. C. (2011). The origin of multicellularity in cyanobacteria. BMC Evolutionary Biology, 11, 45-66. https://doi.org/10.1186/1471-2148-11-45

Schleicher, H., Todt, W., Viladkar, S. G., \& Schmidt, F. (1997). Pb/Pb age determinations on the Newania and Sevattur carbonatites of India: Evidence for multi-stage histories. Chemical Geology, 140, 261-273. https://doi.org/10.1016/S0009-2541(97)00022-3

Schopf, J. W. (1968). Microflora of the Bitter Springs Formation, Late Precambrian, central Australia. Journal of Paleontology, 42, 651-688.

Schopf, W. J., Kudryavtsev, A. B., \& Sergeev, V. N. (2010). Confocal Laser Scanning Microscopy and Raman imagery of the late Neoproterozoic Chichkan microbiota of South Kazakhstan. Journal of Palaeontology, 84, 402-416. https://doi.org/10.1666/09-134.1

Schulz, H. N., \& Schulz, H. D. (2005). Large sulfur bacteria and the formation of phosphorite. Science, 307, 416-418. https://doi.org/10.1126/ science.1103096

Seong-Joo, L., \& Golubic, S. (1999). Microfossil populations in the context of synsedimentary micrite deposition and acicular carbonate precipitation: Mesoproterozoic Gaoyuzhuang Formation, China. Precambrian Research, 96, 183-208. https://doi.org/10.1016/ S0301-9268(99)00004-2

Sergeev, V. N., Gerasimenko, L. M., \& Zavarzin, G. A. (2002). The Proterozoic history and present state of cyanobacteria. Microbiology, 71, 725-740.

She, Z., Strother, P., McMahon, G., Nittler, L. R., Wang, J., Zhang, J., ... Papineau, D. (2013). Terminal Proterozoic cyanobacterial blooms and phosphogenesis documented by the Doushantuo granular phosphorites: In situ micro-analysis of textures and composition. Precambrian Research, 235, 20-35. https://doi.org/10.1016/j.precamres.2013.05.011
Shepard, R. N., Stork, N., Oberstadt, A., Armstrong, D., \& Sumner, D. (2008). Random motility creates reticulate morphologies in cyanobacterial biofilms, leaving phototaxis in the dark. AbSciCon, Abstract 18-15-O.

Shepard, R. N., \& Sumner, D. Y. (2010). Undirected motility of filamentous cyanobacteria produces reticulate mats. Geobiology, 8, 179-190. https://doi.org/10.1111/j.1472-4669.2010.00235.x

Sim, M. S., Liang, B., Petroff, A. P., Evans, A., Klepac-Ceraj, V., Flannery, D. T., ... Bosak, T. (2012). Oxygen-dependent morphogenesis of modern clumped photosynthetic mats and implications for the Archean stromatolite record. Geosciences, 2, 235-259. https://doi.org/10.3390/ geosciences 2040235

Soudry, D. (1987). Ultra-fine structures and genesis of the Campanian Negev high-grade phosphorites (southern Israel). Sedimentology, 34, 641-660. https://doi.org/10.1111/j.1365-3091.1987.tb00792.x

Soudry, D., \& Champetier, Y. (1983). Microbial processes in the Negev phosphorites (southern Israel). Sedimentology, 30, 411-423. https:// doi.org/10.1111/j.1365-3091.1983.tb00680.x

Stal, L. (2000). Cyanobacterial mats and stromatolites. In B. A. Whitton (Ed.), Ecology of cyanobacteria II (pp. 65-125). Amsterdam, Netherlands: Springer.

Sumner, D. Y. (1997). Late Archean calcite-microbe interactions: Two morphologically distinct microbial communities that affected calcite nucleation differently. Palaios, 12, 302-318. https://doi. org/10.2307/3515333

Walter, M. R. (1972). Stromatolites and the biostratigraphy of the Australian Precambrian and Cambrian (Special papers in palaeontology). London, UK: The Palaeontological Association.

Walter, M. R., Bauld, J., \& Brock, T. D. (1976). Microbiology and morphogenesis of columnar stromatolites (Conophyton, Vacerrila) from hot springs in Yellowstone National Park. In M. R. Walter (Ed.), Stromatolites (pp. 273-310). Amsterdam, Netherlands: Elsevier. https://doi.org/10.1016/ S0070-4571(08)71140-3

Wilmeth, D. T., Corsetti, F. A., Bisenic, N., Dornbos, S. Q., Oji, T., \& Gonchigdorj, S. (2015). Punctuated growth of microbial cones within early Cambrian oncoids, Bayan Gol formation, Western Mongolia. Palaios, 30, 836-845. https://doi.org/10.2110/palo.2015.014

Zhang, Y., Yin, L., Xiao, S., \& Knoll, A. (1998). Permineralized fossils from the terminal Proterozoic Doushantuo Formation South China. Journal of Palaeontology, 4, 1-52.

\section{SUPPORTING INFORMATION}

Additional Supporting Information may be found online in the supporting information tab for this article.

How to cite this article: Sallstedt T, Bengtson S, Broman C, Crill PM, Canfield DE. Evidence of oxygenic phototrophy in ancient phosphatic stromatolites from the Paleoproterozoic Vindhyan and Aravalli Supergroups, India. Geobiology.

2018;16:139-159. https://doi.org/10.1111/gbi.12274 